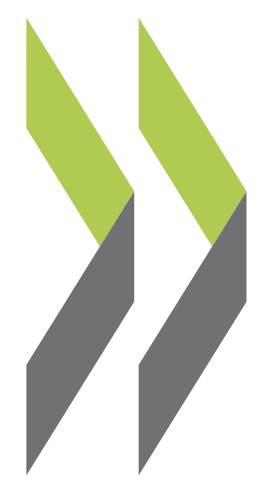

OECD Working Papers on International Investment 2017/01

Foreign direct investment, corruption and the OECD Anti-Bribery Convention

\section{Adrian Blundell-Wignall,}

Caroline Roulet 


\section{OECD WORKING PAPERS ON INTERNATIONAL INVESTMENT}

OECD Working Papers should not be reported as representing the official views of the OECD or of its member countries. The opinions expressed and arguments employed are those of the authors.

Working Papers describe preliminary results or research in progress by the author(s) and are published to stimulate discussion on a broad range of issues on which the OECD works. Comments on Working Papers are welcomed, and may be sent to investment@oecd.org or the Investment Division Directorate for Financial and Enterprise Affairs, OECD, 2 rue André-Pascal, 75775 Paris Cedex 16, France.

The international investment working paper series - including policies and trends and the broader implications of multinational enterprise - is designed to make available to a wide readership selected studies by the OECD Investment Committee, OECD Investment Division staff, or by outside consultants working on OECD Investment Committee projects.

The papers are generally available only in their original language English or French with a summary in the other if available.

\section{OECD WORKING PAPERS ON INTERNATIONAL INVESTMENT are published on www.oecd.org/investment/working-papers.htm.}

This document and any map included herein are without prejudice to the status of or sovereignty over any territory, to the delimitation of international frontiers and boundaries and to the name of any territory, city or area.

The statistical data for Israel are supplied by and under the responsibility of the relevant Israeli authorities. The use of such data by the OECD is without prejudice to the status of the Golan Heights, East Jerusalem and Israeli settlements in the West Bank under the terms of international law.

\section{(c) OECD 2017}

You can copy, download or print OECD content for your own use, and you can include excerpts from OECD publications, databases and multimedia products in your own documents, presentations, blogs, websites and teaching materials, provided that suitable acknowledgment of OECD as source and copyright owner is given. All requests for commercial use and translation rights should be submitted to rights@oecd.org. 


\title{
Foreign direct investment, corruption and the OECD Anti-Bribery Convention
}

by

\author{
Adrian Blundell-Wignall and Caroline Roulet ${ }^{*}$
}

\begin{abstract}
This paper estimates a dynamic foreign direct investment (FDI) gravity model to explore the impact of corruption in general and the OECD Anti-Bribery Convention in particular. The evidence from previous studies in both domains is mixed, probably due to econometric inconsistencies and misuse of data. The more robust findings are that corruption has an insignificant or even positive effect on FDI in the general population. However, adherence to the OECD Anti-Bribery Convention has a clear negative impact on FDI-countries that adhere reduce investments in corrupt destinations.
\end{abstract}

Authorised for release by Pierre Poret, Director, OECD Directorate for Financial and Enterprise Affairs

Keywords: corruption, foreign direct investment, law, institutions

JEL classification: F21, F23

Adrian Blundell-Wignall is the Special Advisor to the OECD Secretary-General on Financial and Enterprise Affairs (www.oecd.org/daf/abw). Caroline Roulet is an Economist and Policy Analyst in the OECD Directorate for Financial and Enterprise Affairs. The authors would like to thank Pierre Poret, Director of the OECD Directorate for Financial and Enterprise Affairs, and Kathryn Gordon, Senior Economist in the OECD Anti-Bribery Division, for their contributions. Any remaining errors are the authors' alone. 


\section{Non-technical summary}

Corruption undermines economic and social progress and steals the future of young generations. Globalisation brings many benefits but also increases opportunities for crimes across multiple jurisdictions and the chance of impunity. The Convention on Combating Bribery of Foreign Public Officials in International Business Transactions (OECD Anti-Bribery Convention), which entered into force in 1999 and has been ratified by 41 OECD and non-OECD countries so far, was designed to address this dark side of globalisation. Under the OECD Anti-Bribery Convention, the Parties are required to criminalise bribery of foreign public officials in international business transactions and to subject themselves to rigorous implementation monitoring.

But does the OECD Anti-Bribery Convention make a difference on the ground? This paper's answer to this question is "yes". While Parties to the OECD Anti-Bribery Convention still have room to sanction bribers more effectively, this paper shows that companies under the Parties' jurisdictions have reduced their investments towards corrupt destinations. Depending on the indices used to measure corruption, a 1 point rise in the index reduces investment flows by companies from Parties to the OECD Anti-Bribery Convention by a range of 4-9\%. A corollary of the findings is less good news: the inclination to use corruption to gain advantages in foreign markets is not reduced in companies from non-Parties that altogether represented $36 \%$ of world exports and 24\% of total direct investment outflows in 2014.

A few previous studies have found some positive impacts of the OECD AntiBribery Convention but the new findings in this paper are more robust as the methodology corrects for shortcomings common in research on the impact of corruption on international investment by using a dynamic model specification, controlling for endogeneity and covering G20 member countries that are not Party to the OECD Anti-Bribery Convention, such as China. Therefore the paper provides a stronger empirical foundation for the international community's legitimate expectation that all G20 countries put their anti-corruption commitments into action and join the OECD Anti-Bribery Convention.

\section{Introduction}

Corruption is a pervasive global problem. Christiane Taubira, the former French Justice Minister, when launching the Foreign Bribery Report in 2014, outlined many of the issues and concluded that corruption is "stealing the future of the world's children". This is no exaggeration. Annual bribes (estimated from micro data extrapolations) amount to around 3\% of world GDP in 2004 (Rose-Ackerman, 2004), and more recent whistleblower evidence in the Unaoil and Panama Papers affairs suggests that corruption may be far more pervasive than previously thought.

A recent OECD study shows that bribing can be profitable in many jurisdictions, even when there is a $100 \%$ chance of being detected. ${ }^{1}$ The OECD Foreign Bribery Report shows that $75 \%$ of bribe cases are paid via intermediaries and that $35 \%$ are

1 "Is foreign bribery an attractive investment in some countries?" looks only at monetary sanctions on corporations. Other sanctions (such as being disqualified from competing in public tenders) are not included, nor are legal costs or spill-over effects of corruption on valuations and their impact on managerial effectiveness (e.g. distraction of board and management time spent dealing with investigations). See OECD (2016a). 
corporate vehicles (often subsidiaries). ${ }^{2}$ In this context, and in light of the pervasiveness of corruption, it is difficult to understand the frequent empirical finding that corruption cost discourages FDI. Corruption often involves investment in countries where governance and property rights are weak and where economic rents are potentially high. This vast industry would hardly exist if it were not somehow attractive to be a part of it compared to investing somewhere else.

This is why the international community has made the fight against corruption a high priority policy objective. The entry into force of the UN Convention against Corruption in 2005 represented a major step forward in international anti-corruption rule-making, covering a wide range of issues and nearly all countries in the world. This global instrument is supported by several regional initiatives, such as the InterAmerican Convention against Corruption and the African Union Convention on Preventing and Combating Corruption.

The OECD Anti-Bribery Convention is an influential and rather specialised part of this growing constellation of anti-corruption instruments. Several features of the OECD Anti-Bribery Convention make it a unique instrument.

- The OECD Anti-Bribery Convention focuses on active bribery -- that is, the offence of bribing foreign public officials (or offering or promising bribes) by individuals and companies involved in international business transactions.

- The commitments Parties make are backed up by an active monitoring process that involves intensive reviews of the laws and enforcement efforts of each Party via peer reviews. This peer monitoring has been going on for more than 16 years and has resulted in major changes in law and enforcement practice among the 41 Parties. ${ }^{3}$

- Parties to the OECD Anti-Bribery Convention account for $64 \%$ of global FDI flows and more than half of world trade. This makes it perhaps the most targeted international anti-bribery instrument; concentrating on laws (e.g. criminalisation of active bribery, corporate liability) and enforcement practices (e.g. mutual legal assistance) designed to ensure that bribery is made a crime and that Parties -- most of them key actors in the global economy -- are active in the enforcement of anti-bribery laws.

The existing empirical literature provides contradictory evidence on the impact of corruption on FDI. There are many potential explanations, which probably result from complex econometric issues not being taken into account, the misuse of data, and choosing samples of countries that do not include all the main players. This paper explores the role of corruption as measured by two well-known indexes, taking stock of some of the lessons to be learned from the different approaches taken in earlier studies; it differs from some of these wholly or in part by:

- Comparing the effects of perceived corruption and the anti-bribery laws on bilateral foreign direct investment (FDI) flows as opposed to the "positions" (stock) variable used in some (although not all) studies.

See OECD (2014).

See OECD (2016b) for information on how the OECD Anti-Bribery Convention has influenced laws in the 41 countries party to the Convention (e.g. 40 have adopted some form of corporate liability; at least 29 have eliminated tax deductibility of bribes). 
- Accepting that the evidence strongly suggests the need to allow for dynamics through a lagged dependent variable in the FDI model, and dealing with the econometric issues that arise in this case.

- Controlling for endogeneity and including a number of different measures of the institutional quality of the countries included alongside the likely endogenous corruption variable with which they are correlated.

- Focusing on the effect of the entry into force (ratification) of the domestic laws that Parties to the OECD Anti-Bribery Convention have enacted. In particular, the paper focuses on the FDI impacts of the OECD Anti-Bribery Convention and associated criminalisation of bribery of foreign public officials in the domestic legal frameworks of the 41 Parties.

- Allowing China and Hong Kong, China to be included along with other larger developing countries (such as India) with complete and adequate data. China and Hong Kong, China account for a large percentage of FDI carried out by countries that have not adhered to the OECD Anti-Bribery Convention.

The overall effect is a positive relationship between corruption and FDI (though often insignificant) for the full population of bilateral relationships, once other key variables have been controlled. However, the interaction effect with adherence to the OECD Anti-Bribery Convention is significantly negative in all cases - the introduction of bribery laws is associated with significantly reducing FDI flows into corrupt regimes (compared to what otherwise might have happened). A number of policy implications are drawn.

\section{Methodological issues in the study of FDI and corruption}

To test issues related to FDI and corruption, one needs sound data concepts for the purpose at hand, an empirical dynamic FDI model, and an econometric approach devoid of important inconsistencies that can bias results when dealing with panel data.

\subsection{Data concepts and coverage}

The OECD Benchmark Definition of Foreign Direct Investment (BMD4) is currently in its $4^{\text {th }}$ edition and is being revised due to a number of well-known problems.

The basic concepts used to construct FDI data are set out in Box 1. If the aim is to build a model of FDI based typically on "gravity" theories about location choices (typically the choice between investing to produce abroad with an affiliate versus exporting from the home country), it is important to use flow data. This is because:

- Stock data are generally unsuitable due to the trended I(1) nature of the "positions" (stock) data. This leads to statistical inference issues.

- The change in the value of "positions" reported in dollars from one period to the next does not consist just of financial flows in the period, but also includes other changes in value. These are captured in the "other changes in financial assets and liabilities account" and include currency valuation changes due to shifts in the exchange rate; other price changes (such as changes in equity prices); and other changes in value, which include such things as write-offs. 
These other changes in value to stock positions have nothing to do with MNE production decisions in response to variables like market size, distance and corruption.

- It is not the case that intellectual property and other intangible assets are colocated with production facilities, as most models implicitly assume. Changes in the location of intangible assets are attributed a value in both "flows" and "positions" and, on occasion, this "value" can be disproportionate to the size of production facilities set up in countries whose markets are the true object of the activity (with a large permanent effect on the stock).

Flows are current transactions taking place within the year and suffer less from valuation effects (which are large for stock data) while outlying observation issues associated with intellectual property flow data are more easily dealt with. ${ }^{4}$

Country coverage also appears to be critical, particularly the inclusion of China. Since the 2008 crisis, China has become the fastest growing outward FDI investor in the world, so that considerable time variation enriches the panel. Countries not party to the OECD Anti-Bribery Convention accounted for around 22\% of global FDI outflows in 2014 (Figure 1). China and Hong Kong, China accounted for around 75\% of outflows for countries not party to the OECD Anti-Bribery Convention (Figure 2). This paper uses data for 54 countries (including China), representing FDI outflows from the source country in resident entities of the partner country. ${ }^{5}$

4 Using flows reduces the effect of this intellectual property anomaly. A huge flow in one year based on intellectual property shifted to, say the Cayman Islands, giving rise to a large stock position there can be treated as an "outlier" and excluded, focusing instead on the flows for production to other destinations for which the theory is better suited. Use of stock data would see a large ongoing stock effect varying due to the exchange rate and other effects. Most studies use the correct flow data, though a number do not, for example, Hines (1995), Wei (2000), Egger and Winner (2005), Kahouli and Maktouf (2015), and Barassi and Zhou (2012).

5 This paper is based on a global sample including the 41 countries party to the OECD Anti-Bribery Convention, other G20 countries and major emerging economies, i.e. all countries for which FDI outflow data are extensively available. The following countries are included in the study: Argentina; Australia; Austria; Belgium; Brazil; Bulgaria; Canada; Chile; China (People's Republic of); Colombia; Czech Republic; Denmark; Estonia; Finland; France; Germany; Greece; Hong Kong, China; Hungary; Iceland; India; Indonesia; Ireland; Israel; Italy; Japan; Korea Latvia; Luxembourg; Malaysia; Mexico; Morocco; Netherlands; New Zealand; Norway; Pakistan; Peru; Philippines; Poland; Portugal; Russian Federation; Singapore; Slovakia; Slovenia; South Africa; Spain; Sweden; Switzerland; Chinese Taipei; Thailand; Tunisia; Turkey; United Kingdom; and the United States. 
Figure 1. Percentage of FDI outflows by countries party and not party to the OECD Anti-Bribery Convention in 2014

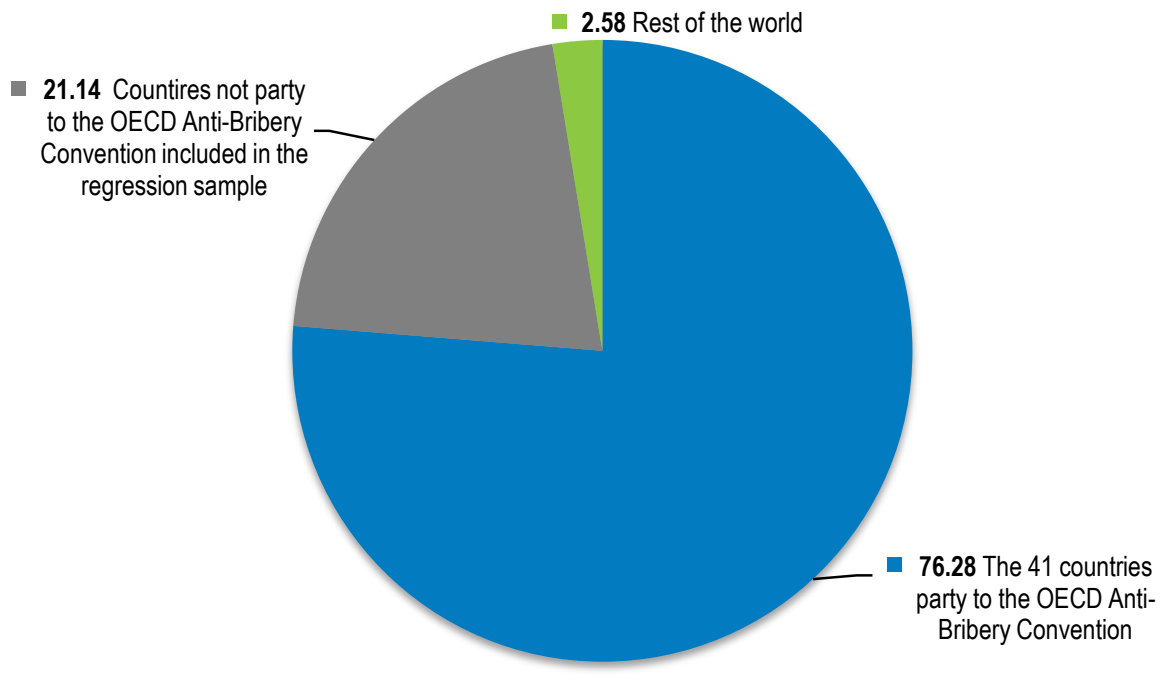

Source: IMF Balance of Payments Statistics (BOPS) database.

Figure 2. Percentage of FDI outflows by economies not party to the OECD Anti-Bribery Convention in 2014 included in the regression sample

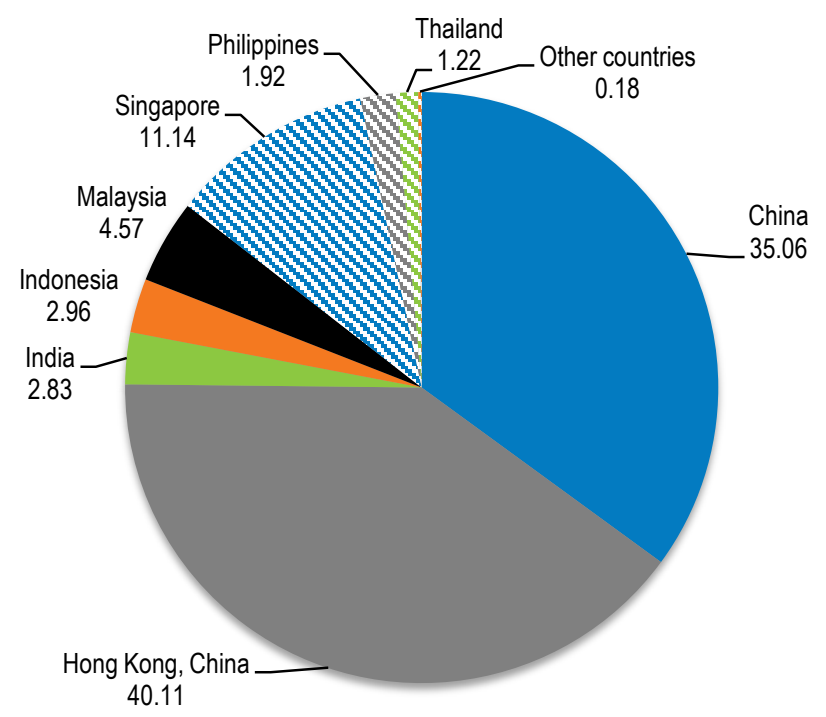

Source: IMF Balance of Payments Statistics (BOPS) database. 


\section{Box 1. Foreign direct investment data definitions}

Foreign direct investment (FDI) is defined as the establishment of a lasting interest in and significant degree of influence over the operations of an enterprise in one economy by an investor in another economy. Ownership of $10 \%$ or more of the voting power in an enterprise by a foreign investor is taken as evidence of such a relationship. FDI statistics cover all crossborder transactions and positions between entities in a foreign direct investment relationship. There are three main components to FDI statistics: 1) financial flows, which capture debt and equity investments between related parties in a specific period; 2) income, which represents the return on equity and debt investment to the direct investor in a specific period; and 3 ) positions, also called stocks, are the value of the accumulated direct investment at a specific point in time. FDI financial flows consist of mergers and acquisitions (M\&A), capacity expanding investment, and financial restructurings, including for tax planning purposes. ${ }^{1}$ Based on components, FDI financial flows consist of equity capital, reinvested earnings, and intercompany debt.

While the cut-off point between FDI and portfolio investment is voting power of $10 \%$ or more, most FDI involves majority control. Where the ownership of voting power is equal to or greater than $10 \%$, then both the debt and equity flows between the entity and its affiliated entities are classified as FDI. For less than $10 \%$ equity holdings, both equity and debt flows are considered to be portfolio in nature.

Table 1. Comparison of FDI and portfolio positions in selected countries

\begin{tabular}{|l|c|c|c|c|c|}
\cline { 2 - 6 } \multicolumn{1}{c|}{} & \multicolumn{2}{c|}{ Coefficient of variation: 2005 - 2013 } & \multicolumn{2}{c|}{ Correlation } \\
\cline { 2 - 6 } \multicolumn{1}{c|}{} & FDI BMD 3 & FDI BMD 4 & TPI & TPI \& FDI BMD 3 & TPI \& FDI BMD 4 \\
\hline United States & 0.23 & 0.20 & 0.23 & 0.78 & 0.98 \\
United Kingdom & 0.12 & 0.11 & 0.17 & 0.83 & 0.70 \\
Germany & 0.19 & 0.16 & 0.18 & 0.92 & 0.84 \\
France & 0.18 & 0.22 & 0.13 & 0.70 & 0.63 \\
Switzerland & 0.34 & 0.33 & 0.16 & 0.90 & 0.89 \\
China & 0.66 & 0.71 & 0.28 & 0.82 & 0.88 \\
\hline \multicolumn{7}{|c|}{ Outward flow } & \\
\hline United States & 0.38 & 0.37 & 2.35 & -0.08 & -0.03 \\
United Kingdom & 0.38 & 1.13 & 2.30 & 0.14 & -0.61 \\
Germany & 0.38 & 0.22 & 2.03 & 0.30 & 0.42 \\
France & 0.61 & 0.46 & 2.92 & 0.04 & 0.11 \\
Switzerland & 0.33 & 0.43 & 2.04 & 0.06 & 0.34 \\
China & 0.48 & - & 1.90 & -0.27 & - \\
\hline
\end{tabular}

Source. Author calculations based on OECD Foreign Direct Investment BMD3 and BMD 4 databases, IMF Balance of Payments Statistics (BOPS) database

Table 1 shows the volatility of outward stocks and flows for FDI, both the BMD3 and BMD4 definitions, and TPI. The new BMD4 concept removes some aspects of special purpose vehicle distortion in the data. All of the stock concepts have low volatility and are highly correlated because they are heavily trended-typically integrated order one [IO(1)] series. The flow data are more volatile and less correlated. In some cases the correlation between FDI and TPI is actually negative over the period where all of the definitions can be compared.

1. Where a company acquires a net financial position or operating interest which is more than $10 \%$ of a host country entity's equity 


\subsection{FDI models}

Gravity models for trade invoke a "physics-like" timeless adjustment depending on relative GDP levels; the distance to trade partners (a proxy for trade costs); regional trade agreements and common language (see Anderson and van Wincoop (2002), Bergstrand and Egger (2007)). ${ }^{6}$ While successful empirically in trade modelling, transposing these to cross-border investment models is far from convincing. Equity and bond purchases do not care about distance as such. To the extent that trade costs are correlated with distance in a stationary way, these costs might influence the initial choice between exporting to a location and setting up production abroad. But this argument is weakened since transport costs have changed dramatically over time reflecting the technology/knowledge content of goods, the advent of standardised shipping containers and other supply chain management techniques. There is also very strong persistence in FDI, once a host is chosen, and repeated investment is typically financed by retained earnings following the setting up of production facilities. This is related to past commitment and has no "distance" motivation. Similar comments apply to common language (China after all is the fastest growing foreign direct investor in Africa, Latin America and Australasia). Such variables may simply act as quasi fixed effects in econometric studies and proxy for other unobserved cross-section dependences. Incorrect inferences may be drawn.

In this paper, flows of FDI between country pairs "i" and " $\mathrm{j}$ " will be influenced by the size of markets as measured by GDP (with a positive sign) as in all gravity models. This is combined with variables that best capture factor considerations and other influences on the choice between direct investment and trade.

- Agglomeration effects have a very long tradition in economics. According to Alfred Marshall, agglomeration gives rise to economies that are external to the firm but internal to a specific geographic area. These economies encompass specialised labour supply, proximity to supply chains, and technical knowledge spill-overs and infrastructure. This will affect both vertical (skill endowment factors) and horizontal (economies that reduce costs) FDI. This parsimonious notion is far more tractable than trying to measure factor endowments and costs of one form or another because it attempts to capture the joint impact of many of them in one concept. Agglomerations should attract FDI.

- Other variables suited to this form of modelling include: financial openness, since the removal of administrative barriers and frictions facilitates FDI; taxation rates which play a key factor in tax planning to facilitate the most profitable ways for companies to carry out $\mathrm{FDI}^{7}{ }^{7}$ and the real effective exchange rate which includes tariff and indirect tax effects on domestic prices and also reflects the extent to which these might be offset by a misaligned nominal exchange rate. The expected influence is negative (for the case of foreign currency per unit of domestic currency - a rise is an appreciation): a high level of the host real effective exchange rate increases the incentive to export to it rather than invest there, while low levels present the case for an export hub located in the country. It must not be forgotten that M\&A activity

6 See also Markusen (2002) and Carr, Markusen and Maskus (2001), Eckhard, Forstid and Markusen (2007).

7 This is why economies such as Switzerland; Netherlands; Ireland; Luxembourg; Hong Kong, China; and Singapore play a larger role than merited by their economic size in the stock FDI data. 
makes up the "lion's share" of FDI. From this perspective, if a country's exchange rate is significantly undervalued in real terms, its assets are cheap and the M\&A component of FDI will be motivated. ${ }^{8}$

Corruption may play a role in the costs and benefits of FDI activity. There are competing hypotheses about what this effect might be. One view "the grabbing hand" is that companies avoid corrupt regimes because corruption enters the cost function of firms. The alternative hypothesis, due to Leff (1964), is that corruption helps FDI by working around regulatory and administrative restriction where bureaucratic and corrupt regimes are involved - sometimes referred to as the "helping hand" hypothesis. The expected influence of corruption on FDI is therefore ambiguous.

Other social indicators are less ambiguous: higher accountability and genuine democracy; a better ability to implement sound policies; confidence in and acceptance of the rules of society; professional and high quality public services; and independence of officials from political pressures; are all characteristics of countries that are attractive to foreign investors. Countries exhibiting political instability, including violence and terrorism, are expected to be unattractive destinations for foreign investment. Corruption however is highly correlated with such variables, presenting problems for establishing causality, interpreting results and drawing policy conclusions.

\subsection{Econometric issues}

A number of econometric issues plague research on FDI (including those with a corruption focus):

- Position (stock) data are typically integrated order one series. Statistical inference from I(1) variables in a panel regression context is not possible (Kao (1999)) even if estimates are consistent.

- Some studies assume strict exogeneity of the regressors when the variables concerned are in fact endogenous. Table 3 shows corruption indexes to be very highly correlated with other social indicators.

- Most studies assume common slope coefficients on the regressors when in fact they are heterogeneous and resulting biases must be addressed.

- The vast majority of studies assume instantaneous adjustment when complex dynamic processes are present (requiring the addition of a lagged dependent variable). FDI displays "persistence" which is readily evident in econometric tests (see Box 2).

- The introduction of a lagged dependent variable in a pooled regression with heterogeneous slope coefficients also introduces inconsistency in the estimates if not treated appropriately, regardless of whether the other regressors are exogenous (Pesaran and Smith (1995)). These biases require treatment.

- Omitted control variables may bias the results.

- Measurement error in the included variables may be important (see Box3).

Many of these issues are not dealt with comprehensively and together in previous studies, which may explain some of the conflicting empirical findings on corruption.

8 See Choi and Jeon (2007) for an econometric study of the role of the exchange rate based on co-integration analysis. 


\section{Box 2. The importance of considering persistence in FDI analysis}

Recent studies of FDI that test for persistence find a highly significant role for the lagged dependent variable after correcting for biases (for example, Kimura and Todo (2010) and Kahouli and Maktouf 2015). There are very good reasons for this. FDI tends to be a multi-year process for companies (unlike portfolio investment). In the beginning, persistence may be related to project sequencing: start-up approval delays through bureaucracy and financing arrangements involving a steady flow of expenditures. Subsequently, FDI is well known to be persistent because of sunk costs. Once an MNE decides to invest for production, it has to set up distribution networks and financial and other services over time, so that an initial investment requires subsequent investments. Depreciation replacement investment also comes into play. Bribery and corruption may contribute to persistence. Hajzler and Rosborough (2016) focus on a theoretical model that recognises the role of corruption in gaining entry to a market and expropriation as a means to remove it, both of which affect the dynamics of FDI and suggest that corruption may in fact be endogenous. Corruption and expropriation are co-determined-the supply side and the demand side interact in a complex dynamic process. Thus corrupt officials in a previous regime may be replaced by a new government and the company runs the risk that the new regime will not respect previous agreements (such as the Shell expropriation in Russia after the Sakhalin II deal was signed). If bribes were paid to the old regime this may precisely increase the probability of expropriation by a new regime, giving rise to the need to avoid this via new bribe arrangements. The company may focus on smaller investments at first and look to postpone taxes and royalties to ensure initial investments are recouped first and bribes help pave the way for such non-standard arrangements. As commitment grows, and investments are not expropriated, bribes may reinforce the persistence of investment and shared rent-seeking outcomes.

\section{Box 3. Measurement error in corruption indicators}

Measurement error is an issue for corruption and governance indicators used in research. The Corruption Perceptions Index (CPI) from Transparency International (TI), which applies only to perceptions of the public sector, is a case in point. The index is standardised on a scale of 0 (bad) to 10 (good), and is based mainly on expert opinions from a few institutions that conduct their own surveys using different metrics (African Development Bank Government Ratings, the Betelsmann Foundation Governance Indicators and Transformation Index; the Economist Intelligence Unit Country Risk ratings; Freedom House Nations in Transit; Global Insight Country Risk Ratings; IMD World Competitiveness Index, Political and Economic Risk Consultancy Asian Intelligence, Political Risk Services International Country Risk Guide; World Bank Country Policy and Institutional Assessment; World Economic Forum Executive Opinion Survey; and World Justice Project Rule of Law Index). The indexes are standardised and averaged with equal weights to obtain the CPI.

Most of the sources rate subsets of countries, and so all components of the CPI are not from the same sources, and nor are the same sources able to be used in all years. The sources look at different aspects of corruption (petty bribery, large scale embezzlement, the amount of money involved, frequency of the survey, perceived effects of bribery, etc.). Corruption, according to Svensson (2005), is related to things that don't change quickly: religion, legal system origins, schooling, democracy, and press freedom, etc. The component scores often jump around when, for example, new corruption discoveries are made. These will tend to bias perceptions of corruption so the statistical transformation by TI must adjust for this. Such transformations and smoothing by TI inevitably result in measurement error. ${ }^{1}$ The World Bank index measures corruption in both the public and private sectors (see Section 3.1 below).

The World Bank also provides a number of other social indicators that condition the environment for corruption and which are based on a common methodology and which might be used to better explore where causality lies for the impact of such concepts on FDI: "Voice and Accountability", "Political Stability and the Absence of Violence", "Government Effectiveness", "Regulatory Quality", "the Rule of Law" and "Corruption". 2

1. Jeong and Weiner (2012) find no link between firms that pay bribes and the CPI.

2. See World Bank Governance Indicators http://info.worldbank.org/governance/wgi/index.aspx\#doc. 


\subsection{Corruption endogeneity and causality}

There are plenty of definitions along the lines of abuse of public or private office for personal gain. From an economic perspective Macrae provides a widely accepted definition: Corruption is an arrangement that involves a private exchange between two parties (the "demander" and the "supplier"), which (1) has an influence on the allocation of resources either immediately or in the future, and (2) involves the use or abuse of public or collective responsibility for private ends. ${ }^{9}$ Where both supply and demand factors are present, the interaction of corruption with other social and economic variables raises questions about causality.

Svensson's survey of the literature on the causes of corruption shows it to be related inversely to: the richness of countries; the degree of openness of economies; the religious orientation; the quality of legal systems; the level of human capital; the freedom of the press; and democratic processes. Corruption is positively related to the extent of regulation. Corruption, in short, is not a conveniently exogenous variable for modelling purposes, but arises out of a number of endogenous and correlated economic and social factors.

This endogeneity too must be considered and allowed for in the econometric method and instruments used.

\subsection{Previous studies concerning the influence of corruption on FDI}

The econometric and data issues noted above allow plenty of scope for conflicting evidence on the effect of both corruption and the OECD bribery laws on FDI. A number of empirical studies have found corruption to be a negative force for economic growth and development (for example Shleifer and Vishny (1993)). Studies that adapt the gravity model from trade theory and find a negative correlation between corruption and FDI include Wei (2000), Habib and Zurawicki (2002), Voyer and Beamish (2004), and Cuervo-Cazurra (2008). Swaleheen and Stansel (2007) find that, conditional on there being some level of economic freedom, corruption actually helps economic growth. A number of empirical studies that adapt the gravity model for FDI find a positive correlation with corruption consistent with the "helping hand" view. These include Akcay (2001), Houston (2007), Eggar and Winner (2005), Al-Sadig (2009) and aspects of Barassi and Zhou (2012). The Al-Sadig contribution shows that controlling for institutional quality of a country is more important than corruption, and the coefficients on the latter become insignificant as an influence on FDI, echoing observations in Gastanaga et. al. (1998), Swaleheen and Stansel (2007), and Houston (2007).

\subsection{Studies addressing the OECD Anti-Bribery Convention}

Economic studies of the effectiveness of the Foreign Corrupt Practices Act (FCPA) -- legislation criminalising foreign bribery that has been in force in the United States since 1977 -- have produced conflicting findings on its effectiveness in influencing foreign investment decisions. Indeed, several studies of the effectiveness of the US Foreign Corrupt Practices Act (FCPA) of 1977 have raised doubts about its effectiveness. On the one hand, Hines (1995) finds that after the introduction of the FCPA, US investors reduced investments in countries with high corruption. This paper uses the level of FDI stock in the regression, however, so that statistical inference

$9 \quad$ Macrae (1982). 
becomes problematic. In contrast, Wei (2000) also using stock level FDI data, finds no additional sensitivity to corruption in the destination country by US investors in comparison to investors from other countries. Neither Hines nor Wei allow for dynamic persistence effects in their FDI models. Smarzynska and Wei (2000), using firm level data, find no evidence that US firms invest less in corrupt countries (though they may invest less in joint ventures as a result of the FCPA, possibly due to its legal liability aspects).

Barrassi and Zhou (2012) use both parametric and non-parametric statistical approaches. They find that corruption figures negatively in the probability of a country becoming a host country for FDI. But once this location choice is controlled for (a country actually becomes a host), the relationship with corruption becomes significantly positive (supporting the "helping hand" view). Using the time dimension of adherence, the study finds that the OECD Anti-Bribery Convention has had only a very limited impact on making MNEs more averse to corruption. Unfortunately, this study also uses stocks of FDI as the dependent variable in the parametric regressions, making statistical inference somewhat questionable. Nor does this study allow for dynamics (the notable persistence of FDI).

The Cuervo-Cazurra study finds support for the efficacy of the OECD Anti-Bribery Convention: "the empirical analysis shows that investors from countries that implemented the OECD Convention... reduced their investment in corruption countries. Investors from the US, which were bound by the Foreign Corrupt Practices Act of 1977, also reduced investments in corruption countries, but only after the OECD Anti-Bribery Convention was in place. ${ }^{, 10} \mathrm{He}$ argues that to reduce the supply of bribes by foreign investors, countries need not only to implement laws against bribery abroad, but also coordinate this implementation with other countries. ${ }^{11}$ While more supportive of the OECD Anti-Bribery Convention, methodological issues are present. The persistence of FDI, when allowed for, proves to be highly significant (and strongly affects the results), but is ignored here. The author uses a random effects model with quasi fixed effects - an ad hoc way of keeping language and distance variables in the presence of some fixed effects. Asymptotic properties of this approach are unclear. Finally, the endogeneity of corruption is not treated with instrumental variables (Arellano and Bond, 1991) or tested against other social and institutional indicators.

Jeong, Y., R.J. Weiner (2012) examine the supply side (illicit payments by firms), asking who bribes and who does not, in the global setting of the United Nations (UN) Oil-for-Food Program (part of UN sanctions on Iraq). Some companies helped Iraq circumvent UN sanctions through bribe payments in the form of illicit surcharges. Using unique transaction-level data uncovered and published through an independent investigation, they examine factors affecting managerial decisions on bribe payments in order to understand why some firms pay bribes, while others do not. Their results suggest that implementation of the OECD Anti-Bribery Convention at home decreases the likelihood of firms engaging in foreign bribery. On the other hand, they find little relationship between the TI Corruption Perception Index and actual bribery by firms. ${ }^{12}$

10 Cuervo-Cazurra (2008), available at SSRN: http://ssrn.com/abstract=1059001.

11 Ibid. page 11.

12 Also using firm level data, Jensen, N.M., and E.J. Malesky (2013), use a specialised survey experiment that shields respondents and reduces reporting bias. They find that after the onset of Phase 3 in 2010, when the risk of punishment under the OECD Anti-Bribery 
There is then considerable conflicting evidence, and methodological issues are often present. The rest of this study will address some of these issues and provide some new evidence on the OECD Anti-Bribery Convention.

\section{The empirical modelling}

\subsection{The model and the variables}

The empirical model used to study the effects of perceived corruption and supplyside anti-bribery laws on the level and pattern of international investment outflows is a relatively parsimonious dynamic version of the gravity model approach discussed earlier. All explanatory variables are measured one year earlier than the dependent variable to reduce endogeneity issues with the regressors. The model takes the following form:

$$
\begin{aligned}
& \mathrm{Ln}_{-} \mathrm{FDI}_{\mathrm{ijt}}=\beta_{0}+\beta_{1} \mathrm{Ln}_{-} \mathrm{FDI}_{\mathrm{ij}, \mathrm{t}-1}+\beta_{2} \mathrm{Ln}_{-} \mathrm{GDP} \_\mathrm{Co}_{\mathrm{i}, \mathrm{t}-1}+\beta_{3} \mathrm{Ln} \_\mathrm{GDP} \_\mathrm{Cd}_{\mathrm{j}, \mathrm{t}-1}+\beta_{4} \\
& \text { Ln_FIOP }_{\mathrm{j}, \mathrm{t}-1}+\beta_{5} \text { TRADE }_{\mathrm{j}, \mathrm{t}-1}+\beta_{6} \text { TAX }_{\mathrm{j}, \mathrm{t}-1}+\beta_{7} \text { Ln_REER }_{\mathrm{j}, \mathrm{t}-1}+\beta_{8} \text { AGGLO }_{\mathrm{j}, \mathrm{t}-1}+\beta_{9} \\
& \mathrm{GI}_{\mathrm{j}, \mathrm{t}-1}+\beta_{10} \operatorname{CORUP}_{\mathrm{j}, \mathrm{t}-1}+\alpha_{\mathrm{ij}}+\zeta_{\mathrm{t}}+\varepsilon_{\mathrm{ijt}}
\end{aligned}
$$

Where:

- Ln_FDI $\mathrm{ij}_{\mathrm{i}, \mathrm{t}}$ is the Foreign Direct Investment variable, measured as the natural logarithm of flows from origin country (i) to destination country (j) at time (t) in billions of US Dollars. The lagged dependent persistence variable is expected to have a positive sign.

- Ln_GDP_Co ${ }_{i, t-1}$ and Ln_GDP_Cd ${ }_{j, t-1}$ are natural logarithms of GDPs in billions of US Dollars for the origin country (i) and the destination country (j) in time $(\mathrm{t}-1)$. Positive signs are expected.

- Ln_FIOP ${ }_{j, t-1}$ is an indicator of financial openness in the destination country. It is the natural logarithm of normalised Chinn-Ito index. ${ }^{13}$ Openness permits FDI more easily and the sign is unambiguously positive.

- TRADE $E_{j, t-1}$ is an indicator of trade openness of the destination country. It is the total trade-to-GDP ratio. The sign on this variable is ambiguous. FDI may be complementary to trade (e.g. marketing and spare parts networks in the destination of exports). On the other hand, trade barriers (a lower ratio) create the incentive to carry out FDI via joint ventures or subsidiaries, as in the tariff jumping theory of Bhagwati et.al. (1992). If the existence or threat of trade restriction is present, and a competitor switches to FDI affiliates, then others will be forced to follow, as in Lin and Saggi (1999).

- $\mathrm{TAX}_{\mathrm{j}, \mathrm{t}-1}$ is statutory tax rate of the destination country. A negative sign is expected.

- $\quad$ Ln_REER ${ }_{j, t-1}$ is the natural logarithm of the real effective exchange rate of the destination country. A negative sign is expected.

- AGGLO $_{j, t-1}$ is the ratio of the aggregation of all FDI inward stocks to gross domestic product of the destination country. A positive sign is expected.

Convention increased, firms from signatory countries reduced their actual bribery relative to their non-signatory competitors.

13 See Chinn and Ito (2006). Chinn and Ito Index is normalised from 0 to 100. 
- CORUP $_{\mathrm{j}, \mathrm{t}-1}$ is alternately CPI $\mathrm{j}_{\mathrm{j},-1}$ and $\mathrm{CCI}_{\mathrm{j}, \mathrm{t}-1}$ which are two indicators of levels of corruption in the destination country. The first corruption indicator is from Transparency International (2005) discussed earlier (rescaled so that larger numbers imply increased corruption). ${ }^{14}$ The second corruption indicator is the measure of "Control of Corruption" developed in the World Bank by Kaufmann, Kraay and Mastruzzi (2003). CCI covers both private and public corruption. ${ }^{15}$ This index includes several indicators measuring the extent to which public power is exercised for private gain, including petty and grand forms of corruption, as well as "capture" of the state by elites and private interests. Thus, comparing the two indicators, the CCI has more coverage (with some sources also providing data on corruption at the household level) versus the narrower CPI which covers corruption in the public sector and as perceived by experts only. ${ }^{16}$ (As noted earlier, the coefficient sign is ambiguous for both indexes in the FDI equation).

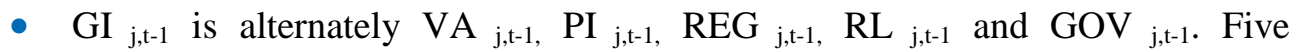
governance indicators developed in the World Bank by Kaufmann, Kraay and Mastruzzi (2003) are used: ${ }^{17}$ :

- VA ${ }_{j, t-1}$ reflects perceptions of the extent to which a destination country's citizens are able to participate in selecting their government, as well as freedom of expression, freedom of association, and a free media (a positive sign).

- $P I_{j, t-1}$ measures perceptions of the likelihood of political instability and/or politically-motivated violence, including terrorism (a negative sign). ${ }^{18}$

- $\mathrm{REG}_{\mathrm{j}, \mathrm{t}-\mathrm{1}}$ reflects perceptions of the ability of the government to formulate and implement sound policies and regulations that permit and promote private sector development (a positive sign).

- $\mathrm{RL}_{\mathrm{j}, \mathrm{t}-1}$ reflects perceptions of the extent to which agents have confidence in and abide by the rules of society, and in particular the quality of contract enforcement, property rights, the police, and the courts, as well as the likelihood of crime and violence (a positive sign).

14 The original indicator measures corruption within an interval of 10 (low corruption) to 0 (high corruption). To avoid awkwardness in the interpretation of the coefficients, the indicator is rescaled so that a higher number indicates higher corruption by subtracting the original index from 10.

15 The indicator has a spread of -2.5 (high corruption) to 2.5 (low corruption). It is rescaled to facilitate the interpretation of the results by deducting it from 2.5 so that a higher number represents higher corruption.

16 See Rohwer (2009).

17 To deal with high correlation issues (see Table 2), these variables are introduced alternately in the model. The World Bank's governance indicators, developed by Kaufmann, Kraay and Mastruzzi (2003), are only available every other year from 1996 onwards. The missing years are completed with the average of indicator in the year before and after each missing year.

18 The indicator has a spread of -2.5 (high political instability) to 2.5 (low political instability). It is rescaled to facilitate the interpretation of the results by deducting it from 2.5 so that a higher number represents higher political instability. 
- $\mathrm{GOV}_{\mathrm{j}, \mathrm{t}-\mathrm{1}}$ reflects perceptions of the quality of public services, the quality of the civil service and the degree of its independence from political pressures, the quality of policy formulation and implementation, and the credibility of the government's commitment to such policies (a positive sign).

Tables 2 and 3 show the descriptive statistics of the data and the correlation matrix of variables. The FDI flow data are from the OECD Foreign Direct Investment Statistics and UNCTAD FDI/TNC databases in millions of US dollars. Data for GDP in millions of US dollars and the trade openness indicator are taken from the International Monetary Fund's (IMF) World Economic Outlook and Direction of Trade Statistics (DOTS) databases. The tax data are based on World Corporate Tax Rates database of the Tax Foundation (http://taxfoundation.org/). The governance indicators data are taken from the World Bank's Worldwide Governance Indicators database (www.govindicators.org). The real effective rate data are based on the Bruegel database (http://bruegel.org/).

The sample is based on an unbalanced panel dataset of annual data on 54 origindestination countries over the period $1997-2012 .{ }^{19}$ Excluding potential outliers, the panel consists of around 16680 observations. ${ }^{20}$

Table 2: Summary of descriptive statistics of the sample

\begin{tabular}{|l|ccccc|}
\hline \multicolumn{1}{|c|}{ Variable } & Obs & Mean & Std. Dev. & Min & Max \\
\hline FDI & 20720 & 26.09 & 17.98 & 1.00 & 172212 \\
GDP_Co & 51516 & 266.63 & 4.63 & 5.07 & 17416 \\
GDP_Cd & 51516 & 266.63 & 4.63 & 5.07 & 17416 \\
FIOP & 51039 & 61.17 & 2.00 & 16.39 & 100 \\
TRADE & 49502 & 0.76 & 0.59 & 0.13 & 4.22 \\
TAX & 51516 & 4.58 & 0.15 & 3.93 & 5.46 \\
REER & 42559 & 2.37 & 3.22 & 1.00 & 16620 \\
AGGLO_FDI & 47965 & 0.29 & 0.07 & 0.10 & 0.58 \\
VA & 51516 & 3.21 & 0.80 & 0.82 & 4.33 \\
PI & 51516 & 2.16 & 0.93 & 0.83 & 5.31 \\
REG & 51516 & 3.41 & 0.74 & 1.42 & 4.73 \\
RL & 51516 & 3.30 & 0.90 & 1.37 & 4.62 \\
GOV & 51516 & 3.44 & 0.84 & 1.59 & 4.93 \\
CPI & 50986 & 4.07 & 2.28 & 0.00 & 8.30 \\
CCI & 51516 & 1.67 & 1.04 & 0.02 & 3.63 \\
\hline
\end{tabular}

Note: The text in this section (3.1) provides explanations relating to this summary table. The GDP data are reported in billions of US dollars.

19 According to Benchmark Definition 3rd Edition, FDI data are available only up to 2012. The definition then changed to Benchmark Definition 4th Edition. So, for consistency reasons, the sample time period for FDI data is 1997-2012.

20 The bilateral FDI flows dataset contains a small number of disinvestment figures shown as negative. This analysis is run by excluding these data. Because our dataset includes null values of FDI and not available data, the following procedure is used: not available data are excluded; where the dependent variable is zero due to rounding in the original source data the natural logarithm of (FDI+1) is used. 


\subsection{Estimation methodology}

Egger and Merlo (2007) argue that ignoring the dynamic nature of FDI could lead to an overestimation of the effect of bilateral treaties, and the same issues arise for bribery and corruption. ${ }^{21}$ Therefore a dyadic dynamic model is used, including the oneyear lagged dependent amongst the set of explanatory variables. This model is estimated using the standard dyadic fixed-effects static OLS estimator. Each dyad of countries has its own intercept. One advantage is that all factors that a country pair has in common and that are time-invariant (i.e., common language and geographical distance) are automatically controlled for. Year fixed effects are introduced in the regressions. Standard errors are clustered on dyads in order to be fully robust toward arbitrary autocorrelation and heteroscedasticity.

Table 3. Correlations amongst the main explanatory variables

\begin{tabular}{|c|c|c|c|c|c|c|c|c|c|c|c|c|c|c|c|}
\hline & Ln_FDI & $\underset{\text { Co }}{\text { Ln_GDP }}$ & $\underset{\mathrm{Cd}}{\text { Ln_GDP }_{-}}$ & Ln_FIOP & TRADE & Ln_REER & $\begin{array}{c}\text { AGGLO_F } \\
\text { DI }\end{array}$ & TAX & VA & PI & REG & RL & GOV & CPI & $\mathrm{CCl}$ \\
\hline Ln_FDI & 1.00 & & & & & & & & & & & & & & \\
\hline Ln_GDP_Co & $\begin{array}{l}0.48 \\
0.00\end{array}$ & 1.00 & & & & & & & & & & & & & \\
\hline Ln_GDP_Cd & $\begin{array}{l}0.31 \\
0.00\end{array}$ & $\begin{array}{l}0.05 \\
0.00\end{array}$ & 1.00 & & & & & & & & & & & & \\
\hline Ln_FIOP & $\begin{array}{l}0.13 \\
0.00\end{array}$ & $\begin{array}{l}0.02 \\
0.00\end{array}$ & $\begin{array}{l}0.14 \\
0.00\end{array}$ & 1.00 & & & & & & & & & & & \\
\hline TRADE & $\begin{array}{l}0.01 \\
0.12\end{array}$ & $\begin{array}{l}0.03 \\
0.00\end{array}$ & $\begin{array}{l}-0.32 \\
0.00\end{array}$ & $\begin{array}{l}0.17 \\
0.00\end{array}$ & 1.00 & & & & & & & & & & \\
\hline Ln_REER & $\begin{array}{l}0.06 \\
0.00\end{array}$ & $\begin{array}{l}0.05 \\
0.00\end{array}$ & $\begin{array}{l}0.21 \\
0.00\end{array}$ & $\begin{array}{l}0.14 \\
0.00\end{array}$ & $\begin{array}{l}0.05 \\
0.00\end{array}$ & 1.00 & & & & & & & & & \\
\hline AGGLO_FDI & $\begin{array}{l}0.08 \\
0.00\end{array}$ & $\begin{array}{l}0.10 \\
0.00\end{array}$ & $\begin{array}{l}-0.17 \\
0.00\end{array}$ & $\begin{array}{l}0.21 \\
0.00\end{array}$ & $\begin{array}{l}0.57 \\
0.00\end{array}$ & $\begin{array}{l}0.17 \\
0.00\end{array}$ & 1.00 & & & & & & & & \\
\hline TAX & $\begin{array}{l}0.07 \\
0.00\end{array}$ & $\begin{array}{l}-0.11 \\
0.00\end{array}$ & $\begin{array}{l}0.38 \\
0.00\end{array}$ & $\begin{array}{l}-0.13 \\
0.00\end{array}$ & $\begin{array}{l}-0.45 \\
0.00\end{array}$ & $\begin{array}{l}-0.07 \\
0.00\end{array}$ & $\begin{array}{l}-0.45 \\
0.00\end{array}$ & 1.00 & & & & & & & \\
\hline VA & $\begin{array}{l}0.11 \\
0.00\end{array}$ & $\begin{array}{l}0.00 \\
0.66\end{array}$ & $\begin{array}{l}0.06 \\
0.00\end{array}$ & $\begin{array}{l}0.66 \\
0.00\end{array}$ & $\begin{array}{l}-0.07 \\
0.00\end{array}$ & $\begin{array}{l}-0.11 \\
0.00\end{array}$ & $\begin{array}{l}0.06 \\
0.00\end{array}$ & $\begin{array}{l}-0.01 \\
0.02\end{array}$ & 1.00 & & & & & & \\
\hline PI & $\begin{array}{l}-0.12 \\
0.00\end{array}$ & $\begin{array}{l}0.01 \\
0.00\end{array}$ & $\begin{array}{l}0.06 \\
0.00\end{array}$ & $\begin{array}{l}-0.57 \\
0.00\end{array}$ & $\begin{array}{l}-0.26 \\
0.00\end{array}$ & $\begin{array}{l}0.03 \\
0.00\end{array}$ & $\begin{array}{l}-0.25 \\
0.00\end{array}$ & $\begin{array}{l}0.18 \\
0.00\end{array}$ & $\begin{array}{l}-0.76 \\
0.00\end{array}$ & 1.00 & & & & & \\
\hline REG & $\begin{array}{l}0.16 \\
0.00\end{array}$ & $\begin{array}{l}0.00 \\
0.55\end{array}$ & $\begin{array}{l}0.04 \\
0.00\end{array}$ & $\begin{array}{l}0.72 \\
0.00\end{array}$ & $\begin{array}{l}0.31 \\
0.00\end{array}$ & $\begin{array}{l}0.04 \\
0.00\end{array}$ & $\begin{array}{l}0.32 \\
0.00\end{array}$ & -0.22 & $\begin{array}{l}0.79 \\
0.00\end{array}$ & $\begin{array}{l}-0.79 \\
0.00\end{array}$ & $\begin{array}{l}1.00 \\
0.00\end{array}$ & & & & \\
\hline RL & $\begin{array}{l}0.15 \\
0.00\end{array}$ & $\begin{array}{l}0.00 \\
0.30\end{array}$ & $\begin{array}{l}0.10 \\
0.00\end{array}$ & $\begin{array}{l}0.63 \\
0.00\end{array}$ & $\begin{array}{l}0.17 \\
0.00\end{array}$ & $\begin{array}{l}0.01 \\
0.08\end{array}$ & $\begin{array}{l}0.23 \\
0.00\end{array}$ & $\begin{array}{l}-0.11 \\
0.00\end{array}$ & $\begin{array}{l}0.83 \\
0.00\end{array}$ & $\begin{array}{l}-0.83 \\
0.00\end{array}$ & $\begin{array}{l}0.92 \\
0.00\end{array}$ & 1.00 & & & \\
\hline GOV & $\begin{array}{l}0.16 \\
0.00\end{array}$ & $\begin{array}{l}-0.01 \\
0.00\end{array}$ & $\begin{array}{l}0.10 \\
0.00\end{array}$ & $\begin{array}{l}0.61 \\
0.00\end{array}$ & $\begin{array}{l}0.21 \\
0.00\end{array}$ & $\begin{array}{l}0.03 \\
0.00\end{array}$ & $\begin{array}{l}0.22 \\
0.00\end{array}$ & $\begin{array}{l}-0.07 \\
0.00\end{array}$ & $\begin{array}{l}0.75 \\
0.00\end{array}$ & $\begin{array}{l}-0.78 \\
0.00\end{array}$ & $\begin{array}{l}0.91 \\
0.00\end{array}$ & $\begin{array}{l}0.95 \\
0.00\end{array}$ & 1.00 & & \\
\hline CPI & $\begin{array}{l}-0.15 \\
0.00\end{array}$ & $\begin{array}{l}0.00 \\
0.94\end{array}$ & $\begin{array}{l}-0.08 \\
0.00\end{array}$ & $\begin{array}{l}-0.60 \\
0.00\end{array}$ & $\begin{array}{l}-0.18 \\
0.00\end{array}$ & $\begin{array}{l}-0.05 \\
0.00\end{array}$ & $\begin{array}{l}-0.24 \\
0.00\end{array}$ & $\begin{array}{l}0.09 \\
0.00\end{array}$ & $\begin{array}{l}-0.75 \\
0.00\end{array}$ & $\begin{array}{l}0.77 \\
0.00\end{array}$ & $\begin{array}{l}-0.90 \\
0.00\end{array}$ & $\begin{array}{l}-0.94 \\
0.00\end{array}$ & $\begin{array}{l}-0.94 \\
0.00\end{array}$ & 1.00 & \\
\hline $\mathrm{CCl}$ & $\begin{array}{l}-0.16 \\
0.00 \\
\end{array}$ & $\begin{array}{l}0.01 \\
0.00 \\
\end{array}$ & $\begin{array}{l}-0.08 \\
0.00\end{array}$ & $\begin{array}{l}-0.60 \\
0.00 \\
\end{array}$ & $\begin{array}{l}-0.17 \\
0.00 \\
\end{array}$ & $\begin{array}{l}-0.02 \\
0.00 \\
\end{array}$ & $\begin{array}{l}-0.22 \\
0.00\end{array}$ & $\begin{array}{l}0.06 \\
0.00\end{array}$ & $\begin{array}{l}-0.79 \\
0.00 \\
\end{array}$ & $\begin{array}{l}0.79 \\
0.00\end{array}$ & $\begin{array}{l}-0.91 \\
0.00 \\
\end{array}$ & $\begin{array}{l}-0.96 \\
0.00 \\
\end{array}$ & $\begin{array}{l}-0.95 \\
0.00 \\
\end{array}$ & $\begin{array}{l}0.98 \\
0.00 \\
\end{array}$ & 1.00 \\
\hline
\end{tabular}

Note: Figures in italics indicate values of the T-statistics that test for null hypothesis of Pearson's coefficients of correlation equal to 0 .

21 The general problem is as follows: Consider the model $: \mathrm{y}_{\mathrm{ij}, \mathrm{t}}=\emptyset_{\mathrm{ij}} \mathrm{y}_{\mathrm{ij}, \mathrm{t}-1}+\beta_{\mathrm{ij}} \mathrm{x}_{\mathrm{ij}, \mathrm{t}}+\mathrm{u}_{\mathrm{ij} \mathrm{j}, \mathrm{t}}$,

where $\mathrm{x}$ is a vector of regressors, $\mathrm{uij}, \mathrm{t}=\mathrm{cij}, \mathrm{t}(\mathrm{y})+\lambda \mathrm{ijfij}, \mathrm{t}+$ e ijt, $\mathrm{c}$ is a vector of specific fixed effects, $\mathrm{f}$ is a vector of unobserved common factors, and $\mathrm{xij}, \mathrm{t}=\mathrm{cij}, \mathrm{t}(\mathrm{x})+$ iijfij, $\mathrm{t}+$ vijt, where $\eta$ is a matrix of factor loadings for the regressors. If the $\varnothing_{\mathrm{ij}}$ are zero, this reduces to the static model, but if not they must be treated as a dynamic model. Since the uij,t is correlated with xij,t and yij,t-1 rendering pooled estimation inconsistent, this must be treated with a GMM estimator. 
However, the above estimator with the lagged dependent variable included suffers from some Nickell (1981) bias, which only vanishes as T, the number of time periods of the panel, becomes large. To eliminate this bias, Arellano and Bond's (1991) generalised method of moments (GMM) estimator is also used. This estimator removes any correlation between the explanatory variables and fixed effects by first differencing the variables. It has the additional advantage that the endogeneity of variables can be explicitly taken into account. A second-order serial correlation test is performed. It is expected to find no serial correlation in the second differenced residuals. The presence of such autocorrelation in the GMM approach can be treated in principle by adding two lags of the dependent variable as instruments, which is implemented in Table 4.

\subsection{FDI, corruption and laws against foreign bribery}

Table 4 summarises all the results obtained by including alternately the additional World Bank governance indicators (regressions 1,2,3,4 and 5) and the two indicators of corruption (regressions A and B).

For the FDI models, the sign on the corruption terms is either positive at the $10 \%$ level (for TI's CPI index) or insignificant (in the case of CCI). The other social indicators have the correct signs, and four of the five (voice VA, political instability PI, sound regulation REG and the rule of law RL) are all supported at the $1 \%$ level in at least one of either the fixed effects OLS or GMM models. This suggests that open, politically stable and well-run countries may be more attractive to foreign investors and these factors may be (if anything) more important than the corruption variables with which they are correlated. This is broadly consistent with the findings of Barrassi and Zhou (2012), and Habib and Zurawicki (2002), who noted that any negative effect of corruption on FDI appeared to weaken when openness and political stability were included.

Regarding the other determinants of FDI flows abroad, most of the findings are consistent with the expected sign. The natural logarithm of GDP in US dollars for the origin country and the destination country (both showing positive estimated coefficients) are strongly supported by the data. The financial openness indicator is positive and significant in the FDI estimations using OLS fixed effects but are positive and insignificant in the equation " $\mathrm{B}$ " Arellano and Bond regressions. The trade variable is negative and strongly supported in the GMM model and is insignificant when estimated with OLS fixed effects. The real exchange rate has the correct negative sign in the GMM, and is otherwise insignificant. The simple tax variable is not supported by the data in any model, underlining the complexity of the issue (SPVs and tax inversion strategies). 
Table 4. Baseline dynamic gravity model on the determinants of bilateral FDI flows

\begin{tabular}{|c|c|c|c|c|c|c|c|c|c|c|c|c|c|c|c|c|c|c|c|c|}
\hline & \multicolumn{2}{|c|}{ FE OLS Dynamic } & \multicolumn{2}{|c|}{ Arellano-Bond GMM } & \multicolumn{2}{|c|}{ FE OLS Dynamic } & \multicolumn{2}{|c|}{ Arellano-Bond GMM } & \multicolumn{2}{|c|}{ FE OLS Dynamic } & \multicolumn{2}{|c|}{ Arellano-Bond GMM } & \multicolumn{2}{|c|}{ FE OLS Dynamic } & \multicolumn{2}{|c|}{ Arellano-Bond GMM } & \multicolumn{2}{|c|}{ FE OLS Dynamic } & \multicolumn{2}{|c|}{ Arellano-Bond GMM } \\
\hline & {$[1 . \mathrm{A}]$} & {$[1 . \mathrm{B}]$} & {$[1 . \mathrm{A}]$} & {$[1 . \mathrm{B}]$} & {$[2 . \mathrm{A}]$} & {$[2 . \mathrm{B}]$} & {$[2 . \mathrm{A}]$} & [2.B] & {$[3 . \mathrm{A}]$} & [3.B] & [3.A] & [3.B] & {$[4 . \mathrm{A}]$} & [4.B] & {$[4 . A]$} & [4.B] & {$[5 . A]$} & {$[5 . \mathrm{B}]$} & {$[5 . \mathrm{A}]$} & [5.B] \\
\hline Ln_lO(-1) & $\begin{array}{r}0.208^{* * *} \\
(13.19)\end{array}$ & $\begin{array}{c}0.208^{\star \star *} \\
(13.22)\end{array}$ & $\begin{array}{l}0.106^{*} \\
(1.66)\end{array}$ & $\begin{array}{l}0.110^{*} \\
(1.71)\end{array}$ & $\begin{array}{c}0.207^{\star \star \star} \\
(13.18)\end{array}$ & $\begin{array}{c}0.208^{\star \star \star} \\
(13.22)\end{array}$ & $\begin{array}{l}0.122^{*} \\
(1.89)\end{array}$ & $\begin{array}{c}0.130^{* *} \\
(2.04)\end{array}$ & $\begin{array}{r}0.208^{* * *} \\
(13.17)\end{array}$ & $\begin{array}{c}0.208^{* * *} \\
(13.20)\end{array}$ & $\begin{array}{l}0.114^{*} \\
(1.81)\end{array}$ & $\begin{array}{l}0.122^{*} \\
(1.93)\end{array}$ & $\begin{array}{c}0.208^{* * *} \\
(13.18)\end{array}$ & $\begin{array}{c}0.208^{\star \star \star} \\
(13.22)\end{array}$ & $\begin{array}{l}0.120^{*} \\
(1.91)\end{array}$ & $\begin{array}{c}0.145^{* *} \\
(2.29)\end{array}$ & $\begin{array}{r}0.208^{* * *} \\
(13.19)\end{array}$ & $\begin{array}{c}0.208^{\star \star \star} \\
(13.23)\end{array}$ & $\begin{array}{l}0.116^{*} \\
(1.81)\end{array}$ & $\begin{array}{c}0.136^{* *} \\
(2.11)\end{array}$ \\
\hline Ln_GDP_Co & $\begin{array}{c}0.524^{* * *} \\
(5.85)\end{array}$ & $\begin{array}{c}0.524^{* * *} \\
(5.86)\end{array}$ & $\begin{array}{c}1.163^{\star \star \star} \\
(5.55)\end{array}$ & $\begin{array}{c}1.131^{\star \star \star *} \\
(5.41)\end{array}$ & $\begin{array}{c}0.525^{* * *} \\
(5.86)\end{array}$ & $\begin{array}{c}0.525^{* * *} \\
(5.86)\end{array}$ & $\begin{array}{c}1.017^{\star \star \star} \\
(4.84)\end{array}$ & $\begin{array}{c}1.021^{\star \star *} \\
(4.89)\end{array}$ & $\begin{array}{c}0.524^{* * *} \\
(5.85)\end{array}$ & $\begin{array}{c}0.525^{* * *} \\
(5.86)\end{array}$ & $\begin{array}{c}1.097^{\star \star \star} \\
(5.27)\end{array}$ & $\begin{array}{c}1.036^{* * *} \\
(5.04)\end{array}$ & $\begin{array}{c}0.524^{* * *} \\
(5.84)\end{array}$ & $\begin{array}{c}0.525^{\star \star \star} \\
(5.85)\end{array}$ & $\begin{array}{c}1.071^{* * *} \\
(5.15)\end{array}$ & $\begin{array}{c}1.035^{* * *} \\
(4.99)\end{array}$ & $\begin{array}{c}0.524^{\star \star \star *} \\
(5.85)\end{array}$ & $\begin{array}{c}0.525^{* * *} \\
(5.85)\end{array}$ & $\begin{array}{c}0.992^{* * *} \\
(4.75)\end{array}$ & $\begin{array}{c}0.934^{* * *} \\
(4.49)\end{array}$ \\
\hline Ln_GDP_Cd & $\begin{array}{c}0.790^{* * *} \\
(5.11)\end{array}$ & $\begin{array}{c}0.764^{* * *} \\
(5.00)\end{array}$ & $\begin{array}{l}-0.152 \\
(-0.58)\end{array}$ & $\begin{array}{r}-0.115 \\
(-0.44)\end{array}$ & $\begin{array}{c}0.749^{* * *} \\
(4.77)\end{array}$ & $\begin{array}{c}0.725^{* * *} \\
(4.66)\end{array}$ & $\begin{array}{l}0.034 \\
(0.15)\end{array}$ & $\begin{array}{l}-0.027 \\
(-0.10)\end{array}$ & $\begin{array}{c}0.843^{* * *} \\
(5.45)\end{array}$ & $\begin{array}{c}0.811^{* * *} \\
(5.32)\end{array}$ & $\begin{array}{l}-0.044 \\
(-0.17)\end{array}$ & $\begin{array}{l}0.028 \\
(0.11)\end{array}$ & $\begin{array}{c}0.817^{* * * *} \\
(5.27)\end{array}$ & $\begin{array}{c}0.790^{* \star *} \\
(5.16)\end{array}$ & $\begin{array}{r}-0.029 \\
(-0.11)\end{array}$ & $\begin{array}{r}-0.017 \\
(-0.07)\end{array}$ & $\begin{array}{c}0.802^{* \star *} \\
(5.18)\end{array}$ & $\begin{array}{c}0.781^{* * *} \\
(5.09)\end{array}$ & $\begin{array}{l}0.087 \\
(0.33)\end{array}$ & $\begin{array}{l}0.144 \\
(0.55)\end{array}$ \\
\hline Ln_FIOP & $\begin{array}{c}0.091 * \star \\
(1.97)\end{array}$ & $\begin{array}{l}0.085^{*} \\
(1.83)\end{array}$ & $\begin{array}{l}0.014 \\
(0.13)\end{array}$ & $\begin{array}{l}0.011 \\
(0.11)\end{array}$ & $\begin{array}{l}0.084^{*} \\
(1.82)\end{array}$ & $\begin{array}{l}0.079^{*} \\
(1.71)\end{array}$ & $\begin{array}{l}0.023 \\
(0.20)\end{array}$ & $\begin{array}{l}0.032 \\
(0.29)\end{array}$ & $\begin{array}{l}0.078^{*} \\
(1.69)\end{array}$ & $\begin{array}{l}0.073 \\
(1.56)\end{array}$ & $\begin{array}{l}0.020 \\
(0.18)\end{array}$ & $\begin{array}{l}0.033 \\
(0.30)\end{array}$ & $\begin{array}{c}0.095^{* *} \\
(2.08)\end{array}$ & $\begin{array}{l}0.090^{*} \\
(1.95)\end{array}$ & $\begin{array}{l}0.096 \\
(0.82)\end{array}$ & $\begin{array}{l}0.120 \\
(1.04)\end{array}$ & $\begin{array}{c}0.098^{* *} \\
(2.12)\end{array}$ & $\begin{array}{c}0.094^{* *} \\
(2.01)\end{array}$ & $\begin{array}{l}-0.002 \\
(-0.02)\end{array}$ & $\begin{array}{l}0.015 \\
(0.14)\end{array}$ \\
\hline TRADE & $\begin{array}{l}0.183 \\
(1.36)\end{array}$ & $\begin{array}{l}0.152 \\
(1.13)\end{array}$ & $\begin{array}{c}-0.350^{*} \\
(-1.71)\end{array}$ & $\begin{array}{l}-0.337^{*} \\
(-1.67)\end{array}$ & $\begin{array}{l}0.174 \\
(1.28)\end{array}$ & $\begin{array}{l}0.139 \\
(1.04)\end{array}$ & $\begin{array}{c}-0.573^{* \star *} \\
(-2.59)\end{array}$ & $\begin{array}{l}-0.565^{* *} \\
(-2.56)\end{array}$ & $\begin{array}{l}0.193 \\
(1.44)\end{array}$ & $\begin{array}{l}0.159 \\
(1.19)\end{array}$ & $\begin{array}{c}-0.496^{* *} \\
(-2.43)\end{array}$ & $\begin{array}{c}-0.499^{\star *} \\
(-2.46)\end{array}$ & $\begin{array}{l}0.169 \\
(1.24)\end{array}$ & $\begin{array}{l}0.139 \\
(1.03)\end{array}$ & $\begin{array}{c}-0.607^{* \star \star} \\
(-2.91)\end{array}$ & $\begin{array}{c}-0.628^{\star \star *} \\
(-3.05)\end{array}$ & $\begin{array}{l}0.186 \\
(1.37)\end{array}$ & $\begin{array}{l}0.155 \\
(1.15)\end{array}$ & $\begin{array}{c}-0.484^{* *} \\
(-2.28)\end{array}$ & $\begin{array}{c}-0.488^{* *} \\
(-2.30)\end{array}$ \\
\hline Ln_REER_Cd & $\begin{array}{r}-0.341 \\
(-1.47)\end{array}$ & $\begin{array}{l}-0.344 \\
(-1.47)\end{array}$ & $\begin{array}{l}0.770 \\
(1.60)\end{array}$ & $\begin{array}{l}0.690 \\
(1.51)\end{array}$ & $\begin{array}{l}-0.311 \\
(-1.33)\end{array}$ & $\begin{array}{r}-0.318 \\
(-1.36)\end{array}$ & $\begin{array}{l}0.579 \\
(1.03)\end{array}$ & $\begin{array}{l}0.720 \\
(1.29)\end{array}$ & $\begin{array}{c}-0.518^{* *} \\
(-2.22)\end{array}$ & $\begin{array}{c}-0.5077^{* *} \\
(-2.17)\end{array}$ & $\begin{array}{l}0.458 \\
(1.00)\end{array}$ & $\begin{array}{l}0.344 \\
(0.76)\end{array}$ & $\begin{array}{l}-0.428^{*} \\
(-1.85)\end{array}$ & $\begin{array}{l}-0.426^{*} \\
(-1.84)\end{array}$ & $\begin{array}{l}0.412 \\
(0.83)\end{array}$ & $\begin{array}{l}0.320 \\
(0.67)\end{array}$ & $\begin{array}{l}-0.389^{*} \\
(-1.68)\end{array}$ & $\begin{array}{l}-0.395^{*} \\
(-1.70)\end{array}$ & $\begin{array}{l}0.176 \\
(0.38)\end{array}$ & $\begin{array}{l}0.020 \\
(0.05)\end{array}$ \\
\hline TAX & $\begin{array}{l}0.600 \\
(1.26)\end{array}$ & $\begin{array}{l}0.605 \\
(1.27)\end{array}$ & $\begin{array}{r}-0.430 \\
(-0.35)\end{array}$ & $\begin{array}{r}-0.043 \\
(-0.03)\end{array}$ & $\begin{array}{l}0.637 \\
(1.34)\end{array}$ & $\begin{array}{l}0.641 \\
(1.35)\end{array}$ & $\begin{array}{r}-0.402 \\
(-0.32)\end{array}$ & $\begin{array}{l}-0.265 \\
(-0.21)\end{array}$ & $\begin{array}{l}0.738 \\
(1.54)\end{array}$ & $\begin{array}{l}0.741 \\
(1.54)\end{array}$ & $\begin{array}{l}-0.359 \\
(-0.30)\end{array}$ & $\begin{array}{l}0.035 \\
(0.03)\end{array}$ & $\begin{array}{l}0.591 \\
(1.24)\end{array}$ & $\begin{array}{l}0.597 \\
(1.25)\end{array}$ & $\begin{array}{l}-0.577 \\
(-0.49)\end{array}$ & $\begin{array}{l}0.038 \\
(0.03)\end{array}$ & $\begin{array}{l}0.550 \\
(1.15)\end{array}$ & $\begin{array}{l}0.562 \\
(1.17)\end{array}$ & $\begin{array}{r}-0.179 \\
(-0.14)\end{array}$ & $\begin{array}{l}0.305 \\
(0.24)\end{array}$ \\
\hline AGGLO & $\begin{array}{c}0.087^{* \star} \\
(2.56)\end{array}$ & $\begin{array}{c}0.090^{* * *} \\
(2.65)\end{array}$ & $\begin{array}{c}0.187^{* * *} \\
(3.16)\end{array}$ & $\begin{array}{c}0.189^{* * *} \\
(3.22)\end{array}$ & $\begin{array}{c}0.090^{* * *} \\
(2.64)\end{array}$ & $\begin{array}{c}0.092^{* * *} \\
(2.69)\end{array}$ & $\begin{array}{c}0.210^{* * *} \\
(3.55)\end{array}$ & $\begin{array}{c}0.218^{* * *} \\
(3.71)\end{array}$ & $\begin{array}{c}0.093^{* * *} \\
(2.75)\end{array}$ & $\begin{array}{c}0.097^{* * *} \\
(2.84)\end{array}$ & $\begin{array}{c}0.205^{* * *} \\
(3.49)\end{array}$ & $\begin{array}{c}0.204^{* * *} \\
(3.49)\end{array}$ & $\begin{array}{c}0.088^{* *} \\
(2.56)\end{array}$ & $\begin{array}{c}0.091 * * * \\
(2.64)\end{array}$ & $\begin{array}{c}0.193^{* * *} \\
(3.32)\end{array}$ & $\begin{array}{c}0.190^{* * *} \\
(3.29)\end{array}$ & $\begin{array}{c}0.092^{* * *} \\
(2.71)\end{array}$ & $\begin{array}{c}0.094^{* * *} \\
(2.74)\end{array}$ & $\begin{array}{c}0.202^{* * *} \\
(3.46)\end{array}$ & $\begin{array}{c}0.203^{* * *} \\
(3.49)\end{array}$ \\
\hline VA & $\begin{array}{c}0.250^{* *} \\
(2.41)\end{array}$ & $\begin{array}{c}0.237^{* *} \\
(2.27)\end{array}$ & $\begin{array}{c}-0.535^{* * *} \\
(-2.60)\end{array}$ & $\begin{array}{c}-0.522^{2 *} \\
(-2.56)\end{array}$ & & - & - & & - & - & - & - & - & - & - & - & - & . & - & 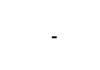 \\
\hline PI & - & - & - & - & $\begin{array}{c}-0.149^{\star \star \star} \\
(-2.71)\end{array}$ & $\begin{array}{c}-0.140^{\star \star} \\
(-2.53)\end{array}$ & $\begin{array}{l}-0.114 \\
(-1.03)\end{array}$ & $\begin{array}{l}-0.144 \\
(-1.31)\end{array}$ & - & - & - & - & - & - & - & - & - & - & - & - \\
\hline REG & - & - & - & - & - & - & - & - & $\begin{array}{c}0.271^{* * *} \\
(2.98)\end{array}$ & $\begin{array}{c}0.255^{* *} \\
(2.57)\end{array}$ & $\begin{array}{l}-0.164 \\
(-0.69)\end{array}$ & $\begin{array}{l}-0.090 \\
(-0.36)\end{array}$ & - & - & - & - & - & - & - & \\
\hline RL & - & - & - & - & - & - & - & - & - & - & - & - & $\begin{array}{l}0.188 \\
(1.61)\end{array}$ & $\begin{array}{l}0.167 \\
(1.37)\end{array}$ & $\begin{array}{c}0.806^{* * *} \\
(2.61)\end{array}$ & $\begin{array}{c}0.955^{* \star *} \\
(3.07)\end{array}$ & - & - & - & - \\
\hline GOV & - & - & - & - & - & - & - & - & - & - & - & - & - & - & - & - & $\begin{array}{r}0.106 \\
(1.17)\end{array}$ & $\begin{array}{l}0.073 \\
(0.79) \\
\end{array}$ & $\begin{array}{r}-0.165 \\
(-0.70)\end{array}$ & $\begin{array}{r}-0.170 \\
(-0.70)\end{array}$ \\
\hline CPI & $\begin{array}{l}0.062^{*} \\
(1.65)\end{array}$ & - & $\begin{array}{l}-0.001 \\
(-0.01)\end{array}$ & & $\begin{array}{l}0.062^{*} \\
(1.65)\end{array}$ & & $\begin{array}{l}0.037 \\
(0.36)\end{array}$ & & $\begin{array}{l}0.073^{*} \\
(1.89)\end{array}$ & - & $\begin{array}{l}-0.035 \\
(-0.34)\end{array}$ & & $\begin{array}{l}0.060 \\
(1.57)\end{array}$ & - & $\begin{array}{l}0.017 \\
(0.17)\end{array}$ & - & $\begin{array}{l}0.059 \\
(1.54)\end{array}$ & - & $\begin{array}{l}-0.004 \\
(-0.04)\end{array}$ & \\
\hline CCI & - & $\begin{array}{l}0.040 \\
(0.42)\end{array}$ & - & $\begin{array}{l}0.135 \\
(0.59)\end{array}$ & - & $\begin{array}{l}0.021 \\
(0.22)\end{array}$ & - & $\begin{array}{l}0.330 \\
(1.41)\end{array}$ & - & $\begin{array}{l}0.061 \\
(0.60)\end{array}$ & - & $\begin{array}{l}0.084 \\
(0.37)\end{array}$ & - & $\begin{array}{l}0.024 \\
(0.25)\end{array}$ & - & $\begin{array}{l}0.273 \\
(1.18)\end{array}$ & - & $\begin{array}{l}0.005 \\
(0.05)\end{array}$ & - & $\begin{array}{l}0.088 \\
(0.39)\end{array}$ \\
\hline \begin{tabular}{|l} 
R-squared \\
N
\end{tabular} & $\begin{array}{l}0.533 \\
13684\end{array}$ & $\begin{array}{l}0.541 \\
13689\end{array}$ & $\begin{array}{c}- \\
10346\end{array}$ & 10349 & $\begin{array}{l}0.544 \\
13684\end{array}$ & $\begin{array}{l}0.554 \\
13689\end{array}$ & 10346 & 10349 & $\begin{array}{l}0.527 \\
13684\end{array}$ & $\begin{array}{l}0.536 \\
13689\end{array}$ & 10346 & 10349 & $\begin{array}{l}0.530 \\
13684\end{array}$ & $\begin{array}{l}0.538 \\
13689\end{array}$ & 10346 & 10349 & $\begin{array}{l}0.531 \\
13684\end{array}$ & $\begin{array}{l}0.540 \\
13689\end{array}$ & 10346 & 10349 \\
\hline $\begin{array}{l}\text { Test no second- } \\
\text { order } \\
\text { autocorrelation (p- } \\
\text { value) }\end{array}$ & - & - & $\begin{array}{c}0.31 \\
(0.754)\end{array}$ & $\begin{array}{c}0.36 \\
(0.722)\end{array}$ & & & $\begin{array}{c}0.44 \\
(0.657)\end{array}$ & $\begin{array}{c}0.54 \\
(0.591)\end{array}$ & . & - & $\begin{array}{c}0.38 \\
(0.707)\end{array}$ & $\begin{array}{c}0.45 \\
(0.652)\end{array}$ & & - & $\begin{array}{c}0.47 \\
(0.639)\end{array}$ & $\begin{array}{c}0.72 \\
(0.469)\end{array}$ & - & ouv & $\begin{array}{c}0.39 \\
(0.697)\end{array}$ & $\begin{array}{c}0.59 \\
(0.554)\end{array}$ \\
\hline
\end{tabular}

Note: This table shows the results of estimating dyadic dynamic fixed effects models for a cross sectional unbalanced panel data on bilateral FDI flows from 54 countries over the period 1997-2012. Constant and year-specific time dummies are included, but coefficients are not reported. The results for the Arellano-Bond GMM estimation refer to robust one-step estimates; t- and z-values reported in parentheses. Standard errors are fully robust toward arbitrary autocorrelation and heteroscedasticity (i.e., standard errors are clustered by home-host dyad with White-Huber corrections). All explanatory variables are one year lagged. *, ** and *** indicate statistical significance at the $10 \%, 5 \%$ and $1 \%$ levels, respectively. 


\subsection{Do laws against foreign bribery shift international FDI patterns?}

Additional estimations explore the effectiveness of laws against bribery abroad in inducing foreign investors to reduce their investment in more corrupt destination countries. The results here are shown in Table 5 which examines interaction with the OECD Anti-Bribery Convention.

As noted earlier, the OECD Anti-Bribery Convention has created a coordination framework in which 41 countries have enacted and/or strengthened laws that punish "active" bribery of foreign public officials -- that is bribery by business people in the course of international business transactions. The laws are designed to reduce the supply of bribes by foreign investors by increasing the perceived legal risks of bribing abroad. By increasing perceived legal risks for businesses and their competitors, it is hoped that the companies and individuals covered by these laws will be more sensitised to corruption, making them more attentive to adopting anti-bribery compliance programmes and, if necessary, to reducing their investments in corrupt countries.

The idea is to test whether FDI to high-corruption-risk host countries weakened after the OECD Anti-Bribery Convention ${ }^{22}$ came into force relative to levels prior to its entry into force. Since companies may not be able to control bribery in high-risk environments found in high-corruption-risk countries, one would expect that investment flows to these countries would weaken from countries party to the OECD Anti-Bribery Convention following ratification.

This hypothesis is tested by considering the 54 origin-destination countries. An interaction term is added to the list of explanatory variables in the FDI model postulated above. A time-variant dummy indicator that takes a value of 1 when investor's country of origin has domestic laws against bribery abroad in force $\mathrm{e}^{23}\left(\mathrm{~T}_{\mathrm{it}}\right)$ and this is multiplied by the indicator of corruption in the destination country. ${ }^{24}$ This hypothesis is supported by the data if the coefficient related to the interaction term is negative and statistically significant. The inclusion of the interaction term precludes

22 The OECD Anti-Bribery Convention entered into force in 1999. It establishes legally binding standards to criminalise bribery of foreign public officials in international business transactions. Countries party to the OECD Anti-Bribery Convention are the 35 OECD countries and 7 non-OECD countries, Argentina, Brazil, Bulgaria, Colombia, Latvia, Russia, and South Africa.

23 For US investors, the time-variant dummy indicator takes a value of 1 for the whole period because the FCPA has been in force since 1977.

24 Such econometric analysis belongs to a class of treatment estimations known as differences-indifferences, where one compares the differences in outcomes before and after the treatment in a group to another group that has not been subject to the treatment. Nevertheless, these increasingly popular difference-in-differences estimations suffer from problems in the standard errors, such as serial correlation (Bertrand, Duflo and Mullainathan, 2004). This paper encompasses a crosssectional panel of 19 years of investment relationships between origin country $i$ and destination country $\mathrm{j}$. The problems of serial correlation will appear at the home-destination country dyad, especially in the interaction between the indicator that the origin country has laws against bribery abroad and the indicator of destination country corruption. This interaction will start taking values above zero once the laws are in place, and will continue with similar values in years after the laws are passed because the level of corruption in the destination country changes little from year to year. For this reason, it is crucial to control in the models for problems in the error term in the home-host dyad. In the previous regressions, the estimation method was defined to account for this problem. The covariance structure is unrestricted over time and panel regressions are run with clustered error terms by home-host dyad using White-Huber corrections. 
using the Arellano and Bond GMM estimator, so the results are shown for the dynamic OLS fixed effects model only. ${ }^{25}$

Table 5. The impact of the OECD Anti-Bribery Convention on bilateral FDI flows

\begin{tabular}{|c|c|c|c|c|c|c|c|c|c|c|}
\hline & [1.A] & [1.B] & [2.A] & [2.B] & [3.A] & [3.B] & [4.A] & [4.B] & {$[5 . \mathrm{A}]$} & [5.B] \\
\hline Ln_IO(-1) & $\begin{array}{c}0.207^{\star \star \star *} \\
(13.16)\end{array}$ & $\begin{array}{c}0.207^{\star * \star} \\
(13.19)\end{array}$ & $\begin{array}{c}0.207^{\star * \star} \\
(13.16)\end{array}$ & $\begin{array}{c}0.207^{\star * *} \\
(13.19)\end{array}$ & $\begin{array}{c}0.207^{\star * \star} \\
(13.14)\end{array}$ & $\begin{array}{c}0.207^{\star \star *} \\
(13.17)\end{array}$ & $\begin{array}{c}0.207^{\star * \star} \\
(13.15)\end{array}$ & $\begin{array}{c}0.208^{\star * *} \\
(13.19)\end{array}$ & $\begin{array}{c}0.207^{\star * *} \\
(13.17)\end{array}$ & $\begin{array}{c}0.208^{* * *} \\
(13.20)\end{array}$ \\
\hline Ln_GDP_Co & $\begin{array}{c}0.553^{\star \star \star} \\
(6.09)\end{array}$ & $\begin{array}{c}0.550^{\star \star \star} \\
(6.07)\end{array}$ & $\begin{array}{c}0.554^{\star \star *} \\
(6.09)\end{array}$ & $\begin{array}{c}0.551^{\star * \star} \\
(6.07)\end{array}$ & $\begin{array}{c}0.553^{\star * \star} \\
(6.08)\end{array}$ & $\begin{array}{c}0.550^{\star \star \star *} \\
(6.07)\end{array}$ & $\begin{array}{c}0.553^{\star \star \star *} \\
(6.08)\end{array}$ & $\begin{array}{c}0.550^{\star \star \star} \\
(6.06)\end{array}$ & $\begin{array}{c}0.554^{\star \star *} \\
(6.09)\end{array}$ & $\begin{array}{c}0.551^{* * *} \\
(6.07)\end{array}$ \\
\hline Ln_GDP_Cd & $\begin{array}{c}0.821^{\star \star *} \\
(5.32)\end{array}$ & $\begin{array}{c}0.798^{\star \star \star} \\
(5.22)\end{array}$ & $\begin{array}{c}0.782^{\star \star \star} \\
(4.98)\end{array}$ & $\begin{array}{c}0.759^{* * *} \\
(4.87)\end{array}$ & $\begin{array}{c}0.870^{\star * *} \\
(5.63)\end{array}$ & $\begin{array}{c}0.842^{\star \star *} \\
(5.51)\end{array}$ & $\begin{array}{c}0.848^{\star \star \star} \\
(5.48)\end{array}$ & $\begin{array}{c}0.824^{\star \star \star} \\
(5.38)\end{array}$ & $\begin{array}{c}0.835^{\star \star \star} \\
(5.41)\end{array}$ & $\begin{array}{c}0.816^{\star \star \star} \\
(5.32)\end{array}$ \\
\hline Ln_FIOP & $\begin{array}{c}0.093^{* *} \\
(2.05)\end{array}$ & $\begin{array}{l}0.088^{*} \\
(1.91)\end{array}$ & $\begin{array}{l}0.086^{*} \\
(1.90)\end{array}$ & $\begin{array}{l}0.082^{*} \\
(1.78)\end{array}$ & $\begin{array}{l}0.081^{*} \\
(1.78)\end{array}$ & $\begin{array}{l}0.076^{*} \\
(1.65)\end{array}$ & $\begin{array}{c}0.099^{* *} \\
(2.19)\end{array}$ & $\begin{array}{c}0.095^{\star *} \\
(2.07)\end{array}$ & $\begin{array}{c}0.100^{* *} \\
(2.20)\end{array}$ & $\begin{array}{c}0.096^{\star *} \\
(2.09)\end{array}$ \\
\hline TRADE & $\begin{array}{l}0.202 \\
(1.50)\end{array}$ & $\begin{array}{l}0.172 \\
(1.29)\end{array}$ & $\begin{array}{l}0.193 \\
(1.43)\end{array}$ & $\begin{array}{l}0.160 \\
(1.19)\end{array}$ & $\begin{array}{l}0.211 \\
(1.57)\end{array}$ & $\begin{array}{l}0.179 \\
(1.34)\end{array}$ & $\begin{array}{l}0.196 \\
(1.44)\end{array}$ & $\begin{array}{l}0.167 \\
(1.24)\end{array}$ & $\begin{array}{l}0.206 \\
(1.53)\end{array}$ & $\begin{array}{l}0.176 \\
(1.31)\end{array}$ \\
\hline Ln_REER_Cd & $\begin{array}{l}-0.372 \\
(-1.63)\end{array}$ & $\begin{array}{l}-0.377 \\
(-1.64)\end{array}$ & $\begin{array}{l}-0.342 \\
(-1.49)\end{array}$ & $\begin{array}{l}-0.351 \\
(-1.52)\end{array}$ & $\begin{array}{c}-0.537^{\star \star} \\
(-2.32)\end{array}$ & $\begin{array}{c}-0.529^{\star *} \\
(-2.29)\end{array}$ & $\begin{array}{l}-0.446^{*} \\
(-1.95)\end{array}$ & $\begin{array}{l}-0.448^{\star} \\
(-1.96)\end{array}$ & $\begin{array}{l}-0.418^{*} \\
(-1.84)\end{array}$ & $\begin{array}{l}-0.426^{*} \\
(-1.87)\end{array}$ \\
\hline TAX & $\begin{array}{l}0.616 \\
(1.30)\end{array}$ & $\begin{array}{l}0.630 \\
(1.33)\end{array}$ & $\begin{array}{l}0.653 \\
(1.38)\end{array}$ & $\begin{array}{l}0.666 \\
(1.40)\end{array}$ & $\begin{array}{l}0.745 \\
(1.56)\end{array}$ & $\begin{array}{l}0.756 \\
(1.57)\end{array}$ & $\begin{array}{l}0.605 \\
(1.27)\end{array}$ & $\begin{array}{l}0.616 \\
(1.29)\end{array}$ & $\begin{array}{l}0.572 \\
(1.20)\end{array}$ & $\begin{array}{l}0.590 \\
(1.24)\end{array}$ \\
\hline AGGLO & $\begin{array}{c}0.084^{\star *} \\
(2.47)\end{array}$ & $\begin{array}{c}0.087^{\star *} \\
(2.55)\end{array}$ & $\begin{array}{c}0.086^{\star \star} \\
(2.53)\end{array}$ & $\begin{array}{c}0.089^{* * *} \\
(2.59)\end{array}$ & $\begin{array}{c}0.090^{\star \star \star *} \\
(2.64)\end{array}$ & $\begin{array}{c}0.094^{\star \star \star} \\
(2.73)\end{array}$ & $\begin{array}{c}0.086^{\star *} \\
(2.50)\end{array}$ & $\begin{array}{c}0.088^{* *} \\
(2.56)\end{array}$ & $\begin{array}{c}0.089^{\star \star \star} \\
(2.60)\end{array}$ & $\begin{array}{c}0.090^{* * *} \\
(2.63)\end{array}$ \\
\hline VA & $\begin{array}{c}0.234^{\star \star} \\
(2.29)\end{array}$ & $\begin{array}{c}0.226^{\star \star} \\
(2.18)\end{array}$ & - & - & - & - & - & - & - & - \\
\hline PI & - & - & $\begin{array}{c}-0.143^{\star \star *} \\
(-2.62)\end{array}$ & $\begin{array}{c}-0.136^{\star \star} \\
(-2.47)\end{array}$ & - & - & - & - & - & - \\
\hline REG & - & - & - & - & $\begin{array}{c}0.253^{\star \star \star} \\
(2.80)\end{array}$ & $\begin{array}{c}0.234^{\star *} \\
(2.43)\end{array}$ & - & - & - & - \\
\hline $\mathbf{R L}$ & - & - & - & - & - & - & $\begin{array}{l}0.135 \\
(1.16)\end{array}$ & $\begin{array}{l}0.114 \\
(0.94)\end{array}$ & - & - \\
\hline GOV & - & - & - & - & - & - & - & - & $\begin{array}{l}0.091 \\
(1.01)\end{array}$ & $\begin{array}{l}0.065 \\
(0.69)\end{array}$ \\
\hline CPI & $\begin{array}{c}0.087^{\star \star} \\
(2.27)\end{array}$ & - & $\begin{array}{c}0.088^{\star \star} \\
(2.30)\end{array}$ & - & $\begin{array}{c}0.097^{\star *} \\
(2.48)\end{array}$ & - & $\begin{array}{c}0.082^{* *} \\
(2.13)\end{array}$ & - & $\begin{array}{c}0.084^{\star \star} \\
(2.17)\end{array}$ & - \\
\hline $\mathrm{CCl}$ & - & $\begin{array}{l}0.110 \\
(1.13)\end{array}$ & - & $\begin{array}{l}0.093 \\
(0.98)\end{array}$ & - & $\begin{array}{l}0.128 \\
(1.24)\end{array}$ & - & $\begin{array}{l}0.082 \\
(0.82)\end{array}$ & - & $\begin{array}{l}0.077 \\
(0.77)\end{array}$ \\
\hline T_CPI & $\begin{array}{c}-0.037^{\star * *} \\
(-3.23)\end{array}$ & - & $\begin{array}{c}-0.037^{\star \star \star} \\
(-3.22)\end{array}$ & - & $\begin{array}{c}-0.036^{\star * *} \\
(-3.15)\end{array}$ & - & $\begin{array}{c}-0.036^{\star * *} \\
(-3.14)\end{array}$ & - & $\begin{array}{c}-0.038^{\star \star *} \\
(-3.28)\end{array}$ & - \\
\hline T_CCl & - & $\begin{array}{c}-0.089^{\star \star \star} \\
(-3.18)\end{array}$ & - & $\begin{array}{c}-0.090^{\star * \star} \\
(-3.17)\end{array}$ & - & $\begin{array}{c}-0.087^{\star \star \star} \\
(-3.10)\end{array}$ & - & $\begin{array}{c}-0.087^{\star \star \star} \\
(-3.09)\end{array}$ & - & $\begin{array}{c}-0.091^{\text {** }} \\
(-3.22)\end{array}$ \\
\hline R-squared & 0.521 & 0.529 & 0.531 & 0.540 & 0.516 & 0.525 & 0.517 & 0.526 & 0.518 & 0.527 \\
\hline$N$ & 13684 & 13689 & 13684 & 13689 & 13684 & 13689 & 13684 & 13689 & 13684 & 13689 \\
\hline
\end{tabular}

Note: This table shows the results of estimating dyadic dynamic fixed effects OLS models for a cross sectional unbalanced panel data on bilateral FDI flows from 54 countries over the period 1997-2012. Constant and year-specific time dummies are included, but coefficients are not reported. Standard errors are fully robust toward arbitrary autocorrelation and heteroscedasticity (i.e., standard errors are clustered by home-host dyad with White-Huber corrections). All explanatory variables are one year lagged. *,** and $* * *$ indicate statistical significance at the $10 \%, 5 \%$ and $1 \%$ levels, respectively.

25 For a continuous variable interacted with a dummy, which is zero at first and then always one from the year the OECD Anti-Bribery Convention becomes effective, the interaction term and the original corruption series become one and the same series from that point for the bilateral relationships concerned. Unfortunately, the differencing techniques of Arellano and Bond do not permit this to happen in the correct year and, in that year, the differences can be extreme. For this reason it is not possible to use a difference-in-differences method with the Arellano and Bond GMM technique. In effect, the latter technique accounts for most of the bias issues regarding endogeneity and the homogeneous slope coefficients assumption, but the same model cannot be used for the difference-in-differences approach. For this reason both models are shown prior to using the interactioneffect approach to gain some insight into the size of the biases that might be present. Only OLS fixed effects are used for the interactions with the OECD Anti-Bribery Convention. 
The inclusion of the interaction between the corruption variables and the bribery laws dummy leads to a clearer picture of the various hypotheses discussed earlier.

- The "helping hand" result for corruption in general is much more clearly supported by the data at the $5 \%$ level in the case of TI's CPI measure, and is positive and insignificant for the World Bank measure.

- The interaction terms are negative and significant at the $1 \%$ level, whether or not the TI measure or the World Bank measure is used. That finding is to be interpreted in the sense that while bribery in general is positively related to FDI, as per the helping hand theory, adhering to the OECD Anti-Bribery Convention and passing bribery laws reduces the effect significantly. In the case of the TI indicator the parameter declines by around $40 \%$. In the case of the CCI World Bank measure, the results are even more encouraging-while the OECD Anti-Bribery Convention positive population coefficient is not significant, that for the Parties to the OECD Anti-Bribery Convention has a negative elasticity which is three times that associated with the TI measure. In this case it could be said that the "grabbing hand" costs cause firms of OECD Anti-Bribery Convention counties to invest less in non-Party jurisdictions, and this finding is strongly supported by the data.

- Three of the five social indicators are supported by the data regardless of the corruption measure used: voice (VA), the likelihood of political instability (PI) and the presence of sound policies and regulations (REG).

These results emphasise the effectiveness of implementing laws against bribery abroad in raising investor awareness to destination-country corruption, and therefore reduce their investments in high-risk-corruption countries. They also highlight the benefits of a coordinated effort at reducing the supply of bribes and of implementing such laws in multiple countries. Indeed, this multi-country effort diminishes the prisoner's dilemma problem faced by investors from a country that is subject to legal constraints when investors from other countries do not face such constraints. The difference between these FDI model results and those of other studies that support the "grabbing hand" view, or which find less support for the OECD Anti-Bribery Convention, may be due to some of the problems in modelling FDI in panel regressions noted earlier. ${ }^{26}$ It may also be due to the inclusion of China and Hong Kong, China as a source and destination location amongst non-Parties to the OECD Anti-Bribery Convention.

\section{Conclusions and policy implications}

A dynamic FDI gravity model is estimated using OLS fixed effects and Arellano and Bond GMM estimators. To account for the differential impact on bilateral investment flows of ratification of the OECD Anti-Bribery Convention in various years by the 41 Parties, an interaction effect between a dummy for the period of adherence and host country corruption is considered. This enables comparison between the coefficient for the general population including non-Parties and the marginal impact for the adhering group. 26 It is not due to the inclusion of other social control variables from the World Bank. Exclusion of
these terms does not change the findings for CPI and CCI in any remarkable way. 
The estimates support the view that perceived corruption in host countries is generally positive and if anything is consistent with the "helping hand" view. In addition to these effects, the paper looks at the differential impact of ratification of the OECD Anti-Bribery Convention. This effect is both statistically and economically significant. The coefficients on the products of the dummy for ratification of the OECD Anti-Bribery Convention and the two measures of perceived corruption (CCI and CPI) can be interpreted as the differential impact elasticity of ratification (that is, when the home country becomes a Party to the OECD Anti-Bribery Convention) on the sensitivity of international investment flows to one point changes the two perceived corruption measures.

The estimations show that a 1 point rise in the TI CPI index will have the helping hand FDI parameter reduced by about $40 \%$ via adherence as captured by the interaction term. For the World Bank index, where there is no significant helping hand effect, a 1 point rise in corruption will see FDI fall by between 4- 9\% for countries that have ratified the OECD Anti-Bribery Convention (depending on whether the CPI or CCI corruption measure is used). These results presumably reflect the compliance risks that host countries with high perceived corruption pose for both investors based in countries where foreign bribery has been criminalised.

The corruption perception indices that are used to characterise corruption in these estimated equations are not policy variables upon which governments can act directly. One might, therefore, ask: what policy changes need to be enacted to get declines in these corruption perception indices?

While this is a complex question that is necessarily linked to country-specific characteristics (e.g. level of development, the relative importance of different sectors, etc.), a broad approach might still involve improving performance in the policy areas that underpin these indices. For the Corruption Control Index, these include: ${ }^{27}$

- increasing trust in politicians (e.g. by disciplining political financing);

- reducing diversion of public funds (e.g. through improved public sector integrity measures and better public financial controls);

- reducing irregular payments in export and import, public utilities, tax collection, public contracts, judicial decisions;

- disciplining state capture;

- lowering the level of "petty" corruption between administration and citizens and between administrations and local and foreign businesses.

These variables are correlated with other World Bank indexes that were found to be even more significant than the corruption index itself for FDI. In particular, voice and accountability of governments in an open society, political stability and well-run countries with sound regulations are attractive to foreign investors.

With respect to the OECD Anti-Bribery Convention, the apparent impact of criminality laws suggests that increasing the number of countries party to the OECD Anti-Bribery Convention and better enforcing laws within these countries could begin to turn the tide further against the corruption industry.

27 See http://info.worldbank.org/governance/wgi/pdf/cc.pdf. 


\section{References}

Ackay, S. (2001), "Is Corruption an Obstacle for Foreign Investors in Developing Countries? Cross-Country Evidence." Yapi Kredi Economic Review, vol. 12 (2).

Al Sadeg, A. (2009), "The Effects of Corruption on FDI Inflows", The Cato Journal, vol. 29 , no. 2.

Anderson, J. E. and E. van Wincoop(2004),'Trade Costs", Journal of Economic Literature, vol. 42.

Arellano, M., Bond, S. (1991), "Some Tests of Specification in Panel Data: Monte Carlo Evidence and an Application to Employment Equations", Review of Economic Studies, vol. 58.

Barrassi M.R.and Y. Zhou (2012), "The Effect of Corruption on Foreign Direct Investment: A Parametric and non-Parametric Analysis", European Journal of Political Economy, vol. 28, No. 3.

Bhagwati, J.N., E. Dinopolous and K.Y. Wong (1992), "Quid Pro Quo Foreign Investment", American Economic Review, vol. 82.

Bertrand, M., Duflo, E., Mullainathan, S. (2004). How much should we trust differences-in-differences estimates? Quarterly Journal of Economics, 119 (1): 249-275.

Bergtrand,J.H. and P. Egger (2007), “A knowledge-and-Physical-Capital Model of international Trade Flows, Foreign Direct Investment, and Multinational Enterprises", Journal of International Economics, vol. 73.

Carr, D.L., J.R. Markusen and K.E Maskus (2001), "Estimating the Knowledge Capital Model of the Multi-National Enterprises", American Economic Review, vol. 91, No. 3, June.

Chinn, M. D. and H. Ito, (2006), "What Matters for Financial Development? Capital Controls, Institutions, and Interactions. Journal of Development Economics, vol. 81 (1).

Cuervo-Cazurra, A. (2008), "The effectiveness of laws against bribery abroad", Journal of International Business Studies, 39 (4).

Egger, P. and V. Merlo (2007), "The Impact of Bilateral Investment Treaties on FDI Dynamics". The World Economy, vol. 30.

Egger, P. and H. Winner (2005), "Evidence on Corruption as an Incentive for Foreign Direct Investment", European Journal of Political Economy, vol. 21.

Ekholm, K., R. Forstid and J.R. Markusen (2007), "Export Platform Foreign Direct Investment", Journal of the European Economic Association, June. 
Gastanaga, V.M., J.B. Nugent and B. Pashamova (1998), "Host Country Reforms and Foreign Direct Investment Inflows: Do They Make a Difference?", World Development, vol.26, No. 7.

Hajler, C. and J. Rosborough, (2016), "Government Corruption and Foreign Direct Investment Under the Threat of Expropriation”, Bank of Canada Working Paper, number 016-13.

Habib, M., Zurawicki, L. (2002), "Corruption and Foreign Direct Investment”, Journal of International Business Studies, 33 (2).

Hines, J. R. (1995), "Forbidden Payment: Foreign Bribery and American Business after 1977”, NBER Working Paper \# 5266. Cambridge, MA: National Bureau of Economic Research.

Houston, D. (2007), “Can Corruption Ever Improve an Economy?” Cato Journal, vol.27 (3).

Jensen, N.M. and E.J. Malesky (2013), "Does the OECD Convention affect bribery? An empirical analysis using the unmatched count technique", mimeo, George Washington School of Business and Duke University.

Jeong, Y., Weiner, R.J. (2012), "Who Bribes? Evidence from the United Nations Oilfor-Food Program”, Strategic Management Journal, vol. 33, No. 12.

Kaufmann, D., Kraay, A., Mastruzzi, M. (2003), Governance Matters III: Governance Indicators for 1996-2002. World Bank Policy Research Working Paper No. 3106, Washington, D.C.

Lin, P. and K. Saggi (1999), “Incentives for FDI Under Imitation”, Canadian Journal of Economics, vol. 32:5.

Kimura H. and Y. Todo (2010), "Is Foreign Aid a Vanguard of Foreign Direct Investment? A Gravity-Equation Approach", World Development, vol. 38.

Kahouli and Maktouf (2015), "The determinants of FDI and the Impact of the Economic Crisis on the Implementation of RTAs: A static and Dynamic Gravity Model”, International Business Review, vol. 24, No. 3.

Macrae, J. (1982). Underdevelopment and the Economics of Corruption: A game Theory Approach" World Development, 10 (8).

Markusen, J. R., (2002), Multinational Firms and the Theory of International Trade. MIT Press, Cambridge, MA.

Nickell, S. (1981). Biases in Dynamic Models with Fixed Effects. Econometrica, vol. 9.

OECD (2016a), "Is foreign bribery an attractive investment in some countries?", OECD Business and Finance Outlook 2016, OECD Publishing, Paris. http://dx.doi.org/10.1787/9789264257573-12-en.

OECD (2016b), Fighting the Crime of Foreign Bribery: The Anti-Bribery Convention and the OECD Working Group on Bribery. www.oecd.org/corruption/Fighting-thecrime-of-foreign-bribery.pdf.

OECD (2014), OECD Foreign Bribery Report: An Analysis of the Crime of Bribery of Foreign Public Officials, OECD Publishing, Paris.

DOI: http://dx.doi.org/10.1787/9789264226616-en. 
OECD Glossary of Statistical Terms.

https://stats.oecd.org/glossary/detail.asp?ID=2092.

Rohwer, A., (2009), "Measuring corruption: A comparison between the Transparency International's Corruption Perception Index and the World Bank Worldwide Governance Indicators”, Research Report, CESifo Group Munich.

Rose-Ackerman, S. (2004), "The Challenge of Poor Governance and Corruption", Global Crises, Global Solutions: First Edition, Edited by Bjørn Lomborg, Cambridge University Press.

Smarzynska, B.K. and J-L Wei (2000), "The Composition of Foreign Direct Investment: Firm Level Evidence", NBER Working Paper, number 7969.

Svensson, J. (2005), "Eight Questions About Corruption", Journal of Economic Perspectives, vol. 19, Number 3.

Swaleheen, M. and D. Stansel (2007), "Economic Freedom, Corruption, and Growth", Cato Journal, vol. 27 No. 3.

Shleifer, A., Vishny, R. (1993), “Corruption”. The Quarterly Journal of Economics, 108 (3): 599-617.

Voyer, P.A. and P.W. Beamish (2004), "The Effect of Corruption on Japanese Foreign Direct Investment. Journal of Business Ethics, 50 (3).

Wei, J-L (2000), "How Taxing is Corruption on International Investors", Review of Economics and Statistics, vol. LXXXII. 


\section{Appendix A}

\section{Robustness Checks}

Robustness checks are undertaken for the FDI results in this paper. Regressions are run over the period 2001-2012, thereby focusing more on the period of rapid FDI growth in China and Hong Kong, China. It also gives more weight to the period when greater OECD progress in working through more advanced phases of the OECD AntiBribery Convention monitoring process is achieved. The results are shown in Tables A.1. andA.2. The main conclusions are broadly consistent with those previously obtained for the full sample. The interaction coefficients between bribery and the OECD Anti-Bribery Convention dummy variables remain negative but with a somewhat stronger elasticity. These findings are consistent with the intensification of the OECD Anti-Bribery Convention monitoring process in the years following its entry into force. 
Table A.1. Baseline dynamic gravity model on the determinants of bilateral FDI flows, 2001-2012

\begin{tabular}{|c|c|c|c|c|c|c|c|c|c|c|c|c|c|c|c|c|c|c|c|c|}
\hline & \multicolumn{2}{|c|}{ FE OLS Dynamic } & \multicolumn{2}{|c|}{ Arellano-Bond GMM } & \multicolumn{2}{|c|}{ FE OLS Dynamic } & \multicolumn{2}{|c|}{ Arellano-Bond GMM } & \multicolumn{2}{|c|}{ FE OLS Dynamic } & \multicolumn{2}{|c|}{ Arellano-Bond GMM } & \multicolumn{2}{|c|}{ FE OLS Dynamic } & \multicolumn{2}{|c|}{ Arellano-Bond GMM } & \multicolumn{2}{|c|}{ FE OLS Dynamic } & \multicolumn{2}{|c|}{ Arellano-Bond GMM } \\
\hline & {$[1 . \mathrm{A}]$} & [1.B] & {$[1 . A]$} & {$[1 . \mathrm{B}]$} & [2.A] & [2.B] & {$[2 . \mathrm{A}]$} & {$[2 . \mathrm{B}]$} & {$[3 . \mathrm{A}]$} & {$[3 . B]$} & {$[3 . \mathrm{A}]$} & {$[3 . B]$} & [4.A] & [4.B] & [4.A] & {$[4 . B]$} & {$[5 . \mathrm{A}]$} & {$[5 . B]$} & {$[5 . \mathrm{A}]$} & {$[5.8]$} \\
\hline Ln_IO(-1) & $\begin{array}{l}0.202^{* * * *} \\
(11.91)\end{array}$ & $\begin{array}{l}0.202^{4 * t} \\
(11.92)\end{array}$ & $\begin{array}{l}0.135^{*} \\
(1.91)\end{array}$ & $\begin{array}{l}0.139 * \star \\
(1.97)\end{array}$ & $\begin{array}{l}0.202^{* * *} \\
(11.90)\end{array}$ & $\begin{array}{l}0.202^{4 * t+} \\
(11.91)\end{array}$ & $\begin{array}{c}0.147^{\star *} \\
(2.06)\end{array}$ & $\begin{array}{c}0.155^{\star *} \\
(2.20)\end{array}$ & $\begin{array}{l}0.202^{* *+*} \\
(11.91)\end{array}$ & $\begin{array}{l}0.202^{2 * *} \\
(11.92)\end{array}$ & $\begin{array}{c}0.146^{* *} \\
(2.13)\end{array}$ & $\begin{array}{c}0.151^{* *} \\
(2.23)\end{array}$ & $\begin{array}{l}0.202^{* * *} \\
(11.90)\end{array}$ & $\begin{array}{l}0.202^{* * *} \\
(11.92)\end{array}$ & $\begin{array}{c}0.152^{\star \star} \\
(2.21)\end{array}$ & $\begin{array}{c}.176^{* *} \\
(2.56)\end{array}$ & $\begin{array}{l}0.202^{* * *} \\
(11.91)\end{array}$ & $\begin{array}{l}0.202^{* * *} \\
(11.92)\end{array}$ & $\begin{array}{c}0.154^{* *} \\
(2.17)\end{array}$ & $\begin{array}{c}0.174^{* *} \\
(2.47)\end{array}$ \\
\hline Ln_GDP_Co & $\begin{array}{c}0.416^{* * * *} \\
(4.39)\end{array}$ & $\begin{array}{c}0.417^{* * * *} \\
(4.41)\end{array}$ & $\begin{array}{c}1.114^{* * * *} \\
(5.24)\end{array}$ & $\begin{array}{c}1.087^{* * *} \\
(5.14)\end{array}$ & $\begin{array}{c}0.417^{* * * *} \\
(4.40)\end{array}$ & $\begin{array}{c}0.418^{*+*} \\
(4.41)\end{array}$ & $\begin{array}{c}0.954^{* * * *} \\
(4.47)\end{array}$ & $\begin{array}{c}0.968^{4 * *} \\
(4.58)\end{array}$ & $\begin{array}{c}0.416^{* *+*} \\
(4.39)\end{array}$ & $\begin{array}{c}0.418^{*+* x} \\
(4.41)\end{array}$ & $\begin{array}{c}1.040^{* \star \star} \\
(4.89)\end{array}$ & $\begin{array}{c}0.978^{\star \star \star *} \\
(4.70)\end{array}$ & $\begin{array}{c}0.417^{* * *} \\
(4.39)\end{array}$ & $\begin{array}{c}0.417^{* * *} \\
(4.40)\end{array}$ & $\begin{array}{l}1.009^{* * *} \\
(4.75)\end{array}$ & $\begin{array}{c}0.984^{\star \star \star} \\
(4.66)\end{array}$ & $\begin{array}{c}0.416^{* * * *} \\
(4.39)\end{array}$ & $\begin{array}{c}0.417^{* * * *} \\
(4.40)\end{array}$ & $\begin{array}{c}0.940^{* * *} \\
(4.43)\end{array}$ & $\begin{array}{c}0.897^{* * * *} \\
(4.27)\end{array}$ \\
\hline Ln_GDP_Cd & $\begin{array}{c}0.738^{* * * *} \\
(4.49)\end{array}$ & $\begin{array}{c}0.697^{* * *} \\
(4.31)\end{array}$ & $\begin{array}{r}-0.163 \\
(-0.62)\end{array}$ & $\begin{array}{l}-0.132 \\
(-0.50)\end{array}$ & $\begin{array}{c}0.697^{* * *} \\
(4.19)\end{array}$ & $\begin{array}{c}0.656^{* * *+} \\
(4.00)\end{array}$ & $\begin{array}{l}0.059 \\
(0.21)\end{array}$ & $\begin{array}{l}-0.013 \\
(-0.05)\end{array}$ & $\begin{array}{c}0.768^{* *+*} \\
(4.68)\end{array}$ & $\begin{array}{c}0.721^{* * * *} \\
(4.47)\end{array}$ & $\begin{array}{l}-0.070 \\
(-0.27)\end{array}$ & $\begin{array}{l}-0.009 \\
(-0.04)\end{array}$ & $\begin{array}{c}0.758^{* * * *} \\
(4.62)\end{array}$ & $\begin{array}{c}0.717^{* * *} \\
(4.44)\end{array}$ & $\begin{array}{l}-0.031 \\
(-0.12)\end{array}$ & $\begin{array}{l}-0.033 \\
(-0.12)\end{array}$ & $\begin{array}{c}0.746^{\text {t*t }} \\
(4.54)\end{array}$ & $\begin{array}{c}0.713^{* * * *} \\
(4.39)\end{array}$ & $\begin{array}{l}0.070 \\
(0.26)\end{array}$ & $\begin{array}{l}0.098 \\
(0.37)\end{array}$ \\
\hline Ln_FIOP & $\begin{array}{l}0.062 \\
(1.20)\end{array}$ & $\begin{array}{l}0.053 \\
(1.03)\end{array}$ & $\begin{array}{l}0.038 \\
(0.33)\end{array}$ & $\begin{array}{l}0.033 \\
(0.29)\end{array}$ & $\begin{array}{l}0.055 \\
(1.05)\end{array}$ & $\begin{array}{l}0.045 \\
(0.88)\end{array}$ & $\begin{array}{l}0.050 \\
(0.40)\end{array}$ & $\begin{array}{l}0.062 \\
(0.51)\end{array}$ & $\begin{array}{l}0.058 \\
(1.13)\end{array}$ & $\begin{array}{l}0.051 \\
(0.99)\end{array}$ & $\begin{array}{l}0.019 \\
(0.16)\end{array}$ & $\begin{array}{l}0.035 \\
(0.30)\end{array}$ & $\begin{array}{l}0.068 \\
(1.31)\end{array}$ & $\begin{array}{l}0.059 \\
(1.16)\end{array}$ & $\begin{array}{l}0.136 \\
(1.08)\end{array}$ & $\begin{array}{l}0.152 \\
(1.24)\end{array}$ & $\begin{array}{l}0.069 \\
(1.34)\end{array}$ & $\begin{array}{l}0.060 \\
(1.18)\end{array}$ & $\begin{array}{l}0.033 \\
(0.27)\end{array}$ & $\begin{array}{l}0.039 \\
(0.33)\end{array}$ \\
\hline TRADE & $\begin{array}{l}0.162 \\
(1.06)\end{array}$ & $\begin{array}{l}0.115 \\
(0.76)\end{array}$ & $\begin{array}{c}-0.344^{*} \\
(-1.66)\end{array}$ & $\begin{array}{l}-0.333 \\
(-1.63)\end{array}$ & $\begin{array}{l}0.149 \\
(0.97)\end{array}$ & $\begin{array}{l}0.099 \\
(0.65)\end{array}$ & $\begin{array}{c}-0.561^{* *} \\
(-2.47)\end{array}$ & $\begin{array}{c}-0.565^{* *} \\
(-2.51)\end{array}$ & $\begin{array}{l}0.179 \\
(1.17)\end{array}$ & $\begin{array}{l}0.127 \\
(0.84)\end{array}$ & $\begin{array}{c}-0.489 * * \\
(-2.37)\end{array}$ & $\begin{array}{c}-0.479^{* * *} \\
(-2.35)\end{array}$ & $\begin{array}{l}0.158 \\
(1.03)\end{array}$ & $\begin{array}{l}0.116 \\
(0.77)\end{array}$ & $\begin{array}{c}-0.602^{\star \star \star *} \\
(-2.84)\end{array}$ & $\begin{array}{c}-0.629^{* * t} \\
(-3.02)\end{array}$ & $\begin{array}{l}0.173 \\
(1.13)\end{array}$ & $\begin{array}{l}0.124 \\
(0.82)\end{array}$ & $\begin{array}{c}-0.479^{* *} \\
(-2.22)\end{array}$ & $\begin{array}{c}-0.482^{* *} \\
(-2.25)\end{array}$ \\
\hline Ln_REER_Cd & $\begin{array}{r}-0.378 \\
(-1.50)\end{array}$ & $\begin{array}{l}-0.386 \\
(-1.53)\end{array}$ & $\begin{array}{l}0.724 \\
(1.51)\end{array}$ & $\begin{array}{l}0.626 \\
(1.37)\end{array}$ & $\begin{array}{l}-0.341 \\
(-1.35)\end{array}$ & $\begin{array}{l}-0.352 \\
(-1.39)\end{array}$ & $\begin{array}{l}0.507 \\
(0.89)\end{array}$ & $\begin{array}{l}0.624 \\
(1.10)\end{array}$ & $\begin{array}{l}-0.460^{*} \\
(-1.82)\end{array}$ & $\begin{array}{c}-0.450^{*} \\
(-1.78)\end{array}$ & $\begin{array}{l}0.363 \\
(0.80)\end{array}$ & $\begin{array}{l}0.269 \\
(0.60)\end{array}$ & $\begin{array}{c}-0.428^{*} \\
(-1.70)\end{array}$ & $\begin{array}{l}-0.427^{\star} \\
(-1.69)\end{array}$ & $\begin{array}{l}0.383 \\
(0.77)\end{array}$ & $\begin{array}{l}0.260 \\
(0.54)\end{array}$ & $\begin{array}{r}-0.396 \\
(-1.58)\end{array}$ & $\begin{array}{r}-0.413 \\
(-1.64)\end{array}$ & $\begin{array}{l}0.157 \\
(0.34)\end{array}$ & $\begin{array}{l}-0.010 \\
(-0.02)\end{array}$ \\
\hline TAX & $\begin{array}{l}0.258 \\
(0.43)\end{array}$ & $\begin{array}{l}0.351 \\
(0.58)\end{array}$ & $\begin{array}{l}-0.873 \\
(-0.63)\end{array}$ & $\begin{array}{l}-0.600 \\
(-0.42)\end{array}$ & $\begin{array}{l}0.299 \\
(0.50)\end{array}$ & $\begin{array}{l}0.391 \\
(0.65)\end{array}$ & $\begin{array}{r}-0.665 \\
(-0.48)\end{array}$ & $\begin{array}{l}-0.556 \\
(-0.39)\end{array}$ & $\begin{array}{l}0.278 \\
(0.46)\end{array}$ & $\begin{array}{l}0.366 \\
(0.60)\end{array}$ & $\begin{array}{r}-1.123 \\
(-0.81)\end{array}$ & $\begin{array}{l}-0.910 \\
(-0.64)\end{array}$ & $\begin{array}{l}0.237 \\
(0.39)\end{array}$ & $\begin{array}{l}0.328 \\
(0.54)\end{array}$ & $\begin{array}{l}-0.983 \\
(-0.74)\end{array}$ & $\begin{array}{c}-0.495 \\
(-0.36)\end{array}$ & $\begin{array}{l}0.231 \\
(0.38)\end{array}$ & $\begin{array}{l}0.325 \\
(0.54)\end{array}$ & $\begin{array}{r}-0.530 \\
(-0.37)\end{array}$ & $\begin{array}{l}-0.246 \\
(-0.17)\end{array}$ \\
\hline AGGLO & $\begin{array}{c}0.092^{+* * *} \\
(2.60)\end{array}$ & $\begin{array}{c}0.092^{* * t} \\
(2.60)\end{array}$ & $\begin{array}{c}0.188^{t * t} \\
(3.14)\end{array}$ & $\begin{array}{c}0.190^{* * t *} \\
(3.19)\end{array}$ & $\begin{array}{c}0.094^{* * * *} \\
(2.65)\end{array}$ & $\begin{array}{c}0.094^{* * *} \\
(2.64)\end{array}$ & $\begin{array}{c}0.209^{\text {t*t }} \\
(3.50)\end{array}$ & $\begin{array}{c}0.218^{* * t} \\
(3.67)\end{array}$ & $\begin{array}{c}0.096^{* *+*} \\
(2.73)\end{array}$ & $\begin{array}{c}0.096^{* * * *} \\
(2.70)\end{array}$ & $\begin{array}{c}0.206^{* * *} \\
(3.47)\end{array}$ & $\begin{array}{c}0.205^{* * *} \\
(3.47)\end{array}$ & $\begin{array}{c}0.094^{* * *} \\
(2.64)\end{array}$ & $\begin{array}{c}0.093^{* * *} \\
(2.63)\end{array}$ & $\begin{array}{c}0.193^{* * *} \\
(3.27)\end{array}$ & $\begin{array}{c}0.1911^{* * *} \\
(3.25)\end{array}$ & $\begin{array}{c}0.096^{* * *} \\
(2.71)\end{array}$ & $\begin{array}{c}0.094^{* * *} \\
(2.66)\end{array}$ & $\begin{array}{c}0.205^{* * *} \\
(3.46)\end{array}$ & $\begin{array}{c}0.207^{* * *} \\
(3.50)\end{array}$ \\
\hline VA & $\begin{array}{c}0.225^{* *} \\
(2.15)\end{array}$ & $\begin{array}{l}0.194^{*} \\
(1.85)\end{array}$ & $\begin{array}{l}-0.480^{* *} \\
(-2.30)\end{array}$ & $\begin{array}{c}-0.460^{* *} \\
(-2.21)\end{array}$ & - & - & - & & - & . & - & . & - & . & . & . & - & - & - & - \\
\hline PI & - & - & - & - & $\begin{array}{c}-0.145^{* \star} \\
(-2.57)\end{array}$ & $\begin{array}{c}-0.131^{* *} \\
(-2.31)\end{array}$ & $\begin{array}{l}-0.107 \\
(-0.93)\end{array}$ & $\begin{array}{l}-0.146 \\
(-1.28)\end{array}$ & & - & - & - & - & - & - & - & - & - & - & - \\
\hline REG & - & . & - & . & . & - & - & . & $\begin{array}{l}0.187^{\star} \\
(1.79)\end{array}$ & $\begin{array}{l}0.134 \\
(1.19)\end{array}$ & $\begin{array}{l}0.032 \\
(0.12)\end{array}$ & $\begin{array}{l}0.144 \\
(0.51)\end{array}$ & - & - & - & . & - & - & - & - \\
\hline RL & - & . & - & . & - & - & - & - & - & - & - & - & $\begin{array}{l}0.125 \\
(0.99)\end{array}$ & $\begin{array}{l}0.066 \\
(0.51)\end{array}$ & $\begin{array}{c}0.812^{* * *} \\
(2.60)\end{array}$ & $\begin{array}{c}0.958^{* \star \star} \\
(3.06)\end{array}$ & - & & - & - \\
\hline Gov & - & . & - & - & - & - & - & - & - & - & - & - & - & - & - & . & $\begin{array}{l}0.089 \\
(0.92)\end{array}$ & $\begin{array}{l}0.034 \\
(0.35)\end{array}$ & $\begin{array}{l}-0.107 \\
(-0.45)\end{array}$ & $\begin{array}{l}-0.105 \\
(-0.43)\end{array}$ \\
\hline CPI & $\begin{array}{l}0.070^{*} \\
(1.70)\end{array}$ & & $\begin{array}{l}0.007 \\
(0.07)\end{array}$ & & $\begin{array}{l}0.070^{*} \\
(1.73)\end{array}$ & & $\begin{array}{l}0.063 \\
(0.59)\end{array}$ & & $\begin{array}{l}0.076^{*} \\
(1.79)\end{array}$ & - & $\begin{array}{c}-0.046 \\
(-0.43)\end{array}$ & - & $\begin{array}{l}0.067 \\
(1.61)\end{array}$ & - & $\begin{array}{l}0.049 \\
(0.46)\end{array}$ & . & $\begin{array}{l}0.067 \\
(1.62)\end{array}$ & & $\begin{array}{l}0.028 \\
(0.24)\end{array}$ & - \\
\hline $\mathrm{cCl}$ & - & $\begin{array}{l}-0.009 \\
(-0.099\end{array}$ & - & $\begin{array}{l}0.111 \\
(0.47)\end{array}$ & - & $\begin{array}{l}-0.024 \\
(-0.24)\end{array}$ & - & $\begin{array}{l}0.341 \\
(1.40)\end{array}$ & & $\begin{array}{l}-0.010 \\
(-0.09)\end{array}$ & - & $\begin{array}{l}0.111 \\
(0.47)\end{array}$ & - & $\begin{array}{l}-0.037 \\
(-0.36)\end{array}$ & - & $\begin{array}{l}0.272 \\
(1.14)\end{array}$ & - & $\begin{array}{r}-0.043 \\
(-0.411\end{array}$ & - & $\begin{array}{l}0.117 \\
(0.49)\end{array}$ \\
\hline R-squared & 0.536 & 0.549 & & & 0.551 & 0.565 & & & 0.534 & 0.548 & & & 0.534 & 0.547 & & & 0.535 & 0.548 & & \\
\hline $\mathrm{N}$ & 12594 & 12594 & 9780 & 9780 & 12594 & 12594 & 9780 & 9780 & 12594 & 12594 & 9780 & 9780 & 12594 & 12594 & 9780 & 9780 & 12594 & 12594 & 9780 & 9780 \\
\hline $\begin{array}{l}\text { Test no second- } \\
\text { order } \\
\text { autocorrelation (p- } \\
\text { value) }\end{array}$ & - & - & $\begin{array}{c}0.87 \\
(0.383)\end{array}$ & $0.9(0.366)$ & - & - & $\begin{array}{c}0.96 \\
(0.339)\end{array}$ & $\begin{array}{c}1.03 \\
(0.305)\end{array}$ & - & - & $0.95(0.34)$ & $\begin{array}{c}1.001 \\
(0.316)\end{array}$ & - & - & $\begin{array}{c}1.04 \\
(0.297)\end{array}$ & $\begin{array}{c}1.26 \\
(0.208)\end{array}$ & - & - & $\begin{array}{c}1.01 \\
(0.315)\end{array}$ & $\begin{array}{c}1.18 \\
(0.237)\end{array}$ \\
\hline
\end{tabular}

Note: This table shows the results of estimating dyadic dynamic fixed effects models for a cross sectional unbalanced panel data on bilateral FDI flows from 54 countries over the period 2001-2012. Constant and year-specific time dummies are included, but coefficients are not reported. The results for the Arellano-Bond GMM estimation refer to robust onestep estimates; $\mathrm{t}$ - and $\mathrm{z}$-values reported in parentheses. Standard errors are fully robust toward arbitrary autocorrelation and heteroscedasticity (i.e., standard errors are clustered by home-host dyad with White-Huber corrections). All explanatory variables are one year lagged. *,** and $* * *$ indicate statistical significance at the $10 \%, 5 \%$ and $1 \%$ levels, respectively. 
Table A.2. The impact of the OECD Anti-Bribery Convention on bilateral FDI flows, 2001-2012

\begin{tabular}{|c|c|c|c|c|c|c|c|c|c|c|}
\hline & [1] & [2] & [1] & [2] & [1] & [2] & [1] & [2] & [1] & [2] \\
\hline Ln_IO(-1) & $\begin{array}{c}0.201^{\star * *} \\
(11.86)\end{array}$ & $\begin{array}{c}0.201^{* \star \star} \\
(11.88)\end{array}$ & $\begin{array}{c}0.201^{* * *} \\
(11.86)\end{array}$ & $\begin{array}{c}0.201^{* * *} \\
(11.87)\end{array}$ & $\begin{array}{c}0.201^{\star * \star} \\
(11.87)\end{array}$ & $\begin{array}{c}0.201^{\star \star *} \\
(11.89)\end{array}$ & $\begin{array}{c}0.201^{\star * *} \\
(11.86)\end{array}$ & $\begin{array}{c}0.201^{\star * *} \\
(11.88)\end{array}$ & $\begin{array}{c}0.201^{* * *} \\
(11.87)\end{array}$ & $\begin{array}{c}0.201^{\star * *} \\
(11.88)\end{array}$ \\
\hline Ln_GDP_Co & $\begin{array}{c}0.463^{\star * *} \\
(4.78)\end{array}$ & $\begin{array}{c}0.455^{\star * *} \\
(4.71)\end{array}$ & $\begin{array}{c}0.464^{* * *} \\
(4.79)\end{array}$ & $\begin{array}{c}0.456^{* * *} \\
(4.72)\end{array}$ & $\begin{array}{c}0.463^{* * *} \\
(4.78)\end{array}$ & $\begin{array}{c}0.456^{* * *} \\
(4.71)\end{array}$ & $\begin{array}{c}0.464^{* * *} \\
(4.78)\end{array}$ & $\begin{array}{c}0.456^{* * *} \\
(4.71)\end{array}$ & $\begin{array}{c}0.463^{\star * *} \\
(4.78)\end{array}$ & $\begin{array}{c}0.455^{* * *} \\
(4.71)\end{array}$ \\
\hline Ln_GDP_Cd & $\begin{array}{c}0.771^{* * *} \\
(4.72)\end{array}$ & $\begin{array}{c}0.727^{\star * *} \\
(4.51)\end{array}$ & $\begin{array}{c}0.729^{* * *} \\
(4.40)\end{array}$ & $\begin{array}{c}0.686^{\star * *} \\
(4.19)\end{array}$ & $\begin{array}{c}0.800^{* * *} \\
(4.89)\end{array}$ & $\begin{array}{c}0.750^{\star * *} \\
(4.65)\end{array}$ & $\begin{array}{c}0.792^{\star * *} \\
(4.85)\end{array}$ & $\begin{array}{c}0.748^{\star * *} \\
(4.63)\end{array}$ & $\begin{array}{c}0.779^{\star * *} \\
(4.76)\end{array}$ & $\begin{array}{c}0.743^{\star * *} \\
(4.59)\end{array}$ \\
\hline Ln_FIOP & $\begin{array}{l}0.067 \\
(1.31)\end{array}$ & $\begin{array}{l}0.057 \\
(1.13)\end{array}$ & $\begin{array}{l}0.059 \\
(1.15)\end{array}$ & $\begin{array}{l}0.049 \\
(0.97)\end{array}$ & $\begin{array}{l}0.064 \\
(1.24)\end{array}$ & $\begin{array}{l}0.056 \\
(1.10)\end{array}$ & $\begin{array}{l}0.073 \\
(1.43)\end{array}$ & $\begin{array}{l}0.064 \\
(1.27)\end{array}$ & $\begin{array}{l}0.074 \\
(1.45)\end{array}$ & $\begin{array}{l}0.065 \\
(1.28)\end{array}$ \\
\hline TRADE & $\begin{array}{l}0.170 \\
(1.12)\end{array}$ & $\begin{array}{l}0.121 \\
(0.80)\end{array}$ & $\begin{array}{l}0.156 \\
(1.02)\end{array}$ & $\begin{array}{l}0.104 \\
(0.69)\end{array}$ & $\begin{array}{l}0.186 \\
(1.22)\end{array}$ & $\begin{array}{l}0.132 \\
(0.87)\end{array}$ & $\begin{array}{l}0.169 \\
(1.11)\end{array}$ & $\begin{array}{l}0.124 \\
(0.82)\end{array}$ & $\begin{array}{l}0.181 \\
(1.19)\end{array}$ & $\begin{array}{l}0.129 \\
(0.86)\end{array}$ \\
\hline Ln_REER_Cd & $\begin{array}{l}-0.416^{*} \\
(-1.68)\end{array}$ & $\begin{array}{c}-0.424^{*} \\
(-1.70)\end{array}$ & $\begin{array}{l}-0.378 \\
(-1.52)\end{array}$ & $\begin{array}{l}-0.389 \\
(-1.56)\end{array}$ & $\begin{array}{c}-0.494^{\star *} \\
(-1.98)\end{array}$ & $\begin{array}{c}-0.484^{*} \\
(-1.93)\end{array}$ & $\begin{array}{l}-0.462^{*} \\
(-1.86)\end{array}$ & $\begin{array}{l}-0.461^{*} \\
(-1.85)\end{array}$ & $\begin{array}{c}-0.433^{\star} \\
(-1.75)\end{array}$ & $\begin{array}{l}-0.451^{*} \\
(-1.81)\end{array}$ \\
\hline TAX & $\begin{array}{l}0.241 \\
(0.40)\end{array}$ & $\begin{array}{l}0.339 \\
(0.56)\end{array}$ & $\begin{array}{l}0.283 \\
(0.47)\end{array}$ & $\begin{array}{l}0.379 \\
(0.63)\end{array}$ & $\begin{array}{l}0.259 \\
(0.43)\end{array}$ & $\begin{array}{l}0.351 \\
(0.58)\end{array}$ & $\begin{array}{l}0.221 \\
(0.37)\end{array}$ & $\begin{array}{l}0.315 \\
(0.52)\end{array}$ & $\begin{array}{l}0.215 \\
(0.36)\end{array}$ & $\begin{array}{l}0.314 \\
(0.52)\end{array}$ \\
\hline AGGLO & $\begin{array}{c}0.089^{\star \star} \\
(2.53)\end{array}$ & $\begin{array}{c}0.090^{\star *} \\
(2.53)\end{array}$ & $\begin{array}{c}0.091^{* * *} \\
(2.58)\end{array}$ & $\begin{array}{c}0.091^{\star *} \\
(2.56)\end{array}$ & $\begin{array}{c}0.094^{\star \star *} \\
(2.65)\end{array}$ & $\begin{array}{c}0.093^{\star * *} \\
(2.62)\end{array}$ & $\begin{array}{c}0.091^{\star *} \\
(2.58)\end{array}$ & $\begin{array}{c}0.091^{\star *} \\
(2.55)\end{array}$ & $\begin{array}{c}0.093^{* * *} \\
(2.64)\end{array}$ & $\begin{array}{c}0.092^{\star *} \\
(2.58)\end{array}$ \\
\hline VA & $\begin{array}{c}0.218^{\star \star} \\
(2.12)\end{array}$ & $\begin{array}{l}0.186^{*} \\
(1.80)\end{array}$ & - & - & - & - & - & - & - & - \\
\hline PI & - & - & $\begin{array}{c}-0.145^{\star \star \star} \\
(-2.58)\end{array}$ & $\begin{array}{c}-0.130^{* *} \\
(-2.32)\end{array}$ & - & - & - & - & - & - \\
\hline REG & - & - & - & - & $\begin{array}{l}0.178^{*} \\
(1.70)\end{array}$ & $\begin{array}{l}0.121 \\
(1.08)\end{array}$ & - & - & - & - \\
\hline RL & - & - & - & - & - & - & $\begin{array}{l}0.104 \\
(0.83)\end{array}$ & $\begin{array}{l}0.043 \\
(0.33)\end{array}$ & - & - \\
\hline GOV & - & - & - & - & - & - & - & - & $\begin{array}{l}0.088 \\
(0.91)\end{array}$ & $\begin{array}{l}0.032 \\
(0.32)\end{array}$ \\
\hline CPI & $\begin{array}{c}0.116^{\star \star \star} \\
(2.78)\end{array}$ & - & $\begin{array}{c}0.117^{\star \star *} \\
(2.83)\end{array}$ & - & $\begin{array}{c}0.122^{\star \star \star} \\
(2.83)\end{array}$ & - & $\begin{array}{c}0.112^{* \star *} \\
(2.65)\end{array}$ & - & $\begin{array}{c}0.115^{* \star \star} \\
(2.69)\end{array}$ & - \\
\hline $\mathrm{CCl}$ & - & $\begin{array}{l}0.084 \\
(0.81)\end{array}$ & - & $\begin{array}{l}0.072 \\
(0.71)\end{array}$ & - & $\begin{array}{l}0.081 \\
(0.72)\end{array}$ & - & $\begin{array}{l}0.053 \\
(0.49)\end{array}$ & - & $\begin{array}{l}0.052 \\
(0.50)\end{array}$ \\
\hline T_CPI & $\begin{array}{c}-0.059^{* * *} \\
(-4.12)\end{array}$ & - & $\begin{array}{c}-0.059^{* * *} \\
(-4.13)\end{array}$ & - & $\begin{array}{c}-0.059^{* * *} \\
(-4.09)\end{array}$ & - & $\begin{array}{c}-0.059^{* * *} \\
(-4.11)\end{array}$ & - & $\begin{array}{c}-0.059^{* * *} \\
(-4.13)\end{array}$ & - \\
\hline T_CCl & - & $\begin{array}{c}-0.126^{\star * *} \\
(-3.63)\end{array}$ & - & $\begin{array}{c}-0.128^{* * *} \\
(-3.64)\end{array}$ & - & $\begin{array}{c}-0.126^{\star * *} \\
(-3.60)\end{array}$ & - & $\begin{array}{c}-0.127^{\star \star \star} \\
(-3.65)\end{array}$ & - & $\begin{array}{c}-0.128^{\star \star *} \\
(-3.65)\end{array}$ \\
\hline R-squared & 0.519 & 0.533 & 0.532 & 0.548 & 0.517 & 0.533 & 0.516 & 0.531 & 0.518 & 0.532 \\
\hline$N$ & 12594 & 12594 & 12594 & 12594 & 12594 & 12594 & 12594 & 12594 & 12594 & 12594 \\
\hline
\end{tabular}

Note: This table shows the results of estimating dyadic dynamic fixed effects OLS models for a cross sectional unbalanced panel data on bilateral FDI flows from 54 countries over the period 2001-2012. Constant and year-specific time dummies are included, but coefficients are not reported. Standard errors are fully robust toward arbitrary autocorrelation and heteroscedasticity (i.e., standard errors are clustered by home-host dyad with White-Huber corrections). All explanatory variables are one year lagged. *,* and *** indicate statistical significance at the $10 \%, 5 \%$ and $1 \%$ levels, respectively. 


\section{OECD Working Papers on International Investment}

\section{www.oecd.org/investment/working-papers.htm}

2016/3 State-to-State dispute settlement and the interpretation of investment treaties

2016/2 Investment policies related to national security

2016/1 The legal framework applicable to joint interpretive agreements of investment treaties

2015

2015/3 Currency-based measures targeting banks - Balancing national regulation of risk and financial openness

2015/2 Investment Treaties over Time - Treaty Practice and Interpretation in a Changing World

2015/1 The Policy Landscape for International Investment by Government-controlled Investors: A Fact Finding Survey

2014

2014/3 Investment Treaties and Shareholder Claims: Analysis of Treaty Practice

2014/2 Investment Treaties and Shareholder Claims for Reflective Loss: Insights from Advanced Systems of Corporate Law

2014/1 Investment Treaty Law, Sustainable Development and Responsible Business Conduct: A Fact Finding Survey

\section{3}

2013/4 Temporal validity of international investment agreements: a large sample survey of treaty provisions

2013/3 Investment treaties as corporate law: Shareholder claims and issues of consistency

2013/2 Lessons from Investment Policy Reform in Korea

2013/1 China Investment Policy: an Update

2012

2012/3 Investor-state dispute settlement: A scoping paper for the investment policy community

2012/2 Dispute settlement provisions in international investment agreements: A large sample survey

2012/1 Corporate greenhouse gas emission reporting: A stocktaking of government schemes

2011

2011/2 Defining and measuring green FDI: An exploratory review of existing work and evidence

2011/1 Environmental concerns in international investment agreements: a survey

2010

2010/3 OECD's FDI Restrictiveness Index: 2010 Update

2010/2 Foreign state immunity and foreign government controlled investors

2010/1 Intellectual property rights in international investment agreements

2006

2006/4 OECD's FDI regulatory restrictiveness index: Revision and extension to more economies

2006/3 Interpretation of the Umbrella Clause in Investment Agreements

2006/2 Investor-State Dispute Settlement in Infrastructure Projects

2006/1 Improving the System of Investor-State Dispute Settlement: An Overview 
2005/3 Corporate Responsibility Practices of Emerging Market Companies - A Fact-Finding Study

2005/2 Multilateral Influences on the OECD Guidelines for Multinational Enterprises

2005/1 Transparency and Third Party Participation in Investor-State Dispute Settlement Procedures

2004

2004/6 Mobilising Investment for Development: Role of ODA - The 1993-2003 Experience in Vietnam

2004/5 ODA and Investment for Development: What Guidance can be drawn from Investment Climate Scoreboards?

2004/4 Indirect Expropriation and the Right to Regulate in International Investment Law

2004/3 Fair and Equitable Treatment Standard in International Investment Law

2004/2 Most-Favoured-Nation Treatment in International Investment Law

2004/1 Relationships between International Investment Agreements

2003

2003/2 Business Approaches to Combating Corrupt Practices

2003/1 Incentives-based Competition for Foreign Direct Investment: The Case of Brazil

2002

2002/2 Managing Working Conditions in the Supply Chain: A Fact-Finding Study of Corporate Practices

2002/1 Multinational Enterprises in Situations of Violent Conflict and Widespread Human Rights Abuses

2001

2001/6 Codes of Corporate Conduct: Expanded review of their contents

2001/5 The OECD Guidelines for Multinational Enterprises and other corporate responsibility instruments

2001/4 Public policy and voluntary initiatives: What roles have governments played?

2001/3 Making codes of corporate conduct work: Management control systems and corporate responsibility

2001/2 Corporate Responsibility: Results of a fact-finding mission on private initiatives

2001/1 Private Initiatives for Corporate Responsibility: An Analysis

2000

2000/5 Recent trends, policies and challenges in South East European countries

2000/4 Main determinants and impacts of FDI on China's economy

2000/3 Lithuania: Foreign Direct Investment Impact and Policy Analysis

2000/2 Investment Patterns in a Longer-Term Perspective

2000/1 Bribery and the business sector: Managing the relationship

1999

1999/3 Rules for the Global Economy: Synergies between Voluntary and Binding Approaches

1999/2 Deciphering Codes of Corporate Conduct: A Review of their Contents

1999/1 Southeast Asia: the Role of FDI Policies in Development

1998

1998/1 Survey of OECD work on international investment 